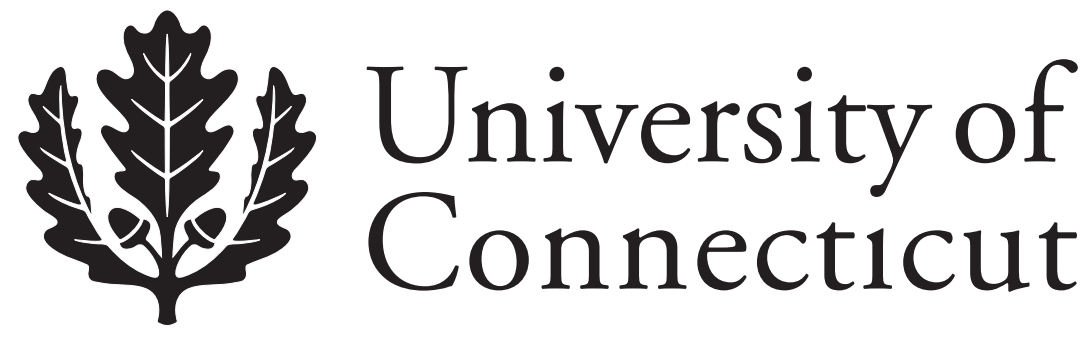

Department of Economics Working Paper Series

\title{
An alternative method for measuring financial frictions
}

Uluc Aysun

University of Connecticut

Working Paper 2009-34

October 2009

341 Mansfield Road, Unit 1063

Storrs, CT 06269-1063

Phone: (860) 486-3022

Fax: (860) 486-4463

http://www.econ.uconn.edu/

This working paper is indexed on RePEc, http://repec.org/ 


\begin{abstract}
Costly state verification models predict that the sensitivity of borrowing costs to financial leverage is positively related to the level of state verification costs (financial frictions). This paper constructs a measure of financial frictions that is consistent with this prediction of theory. Using bond deals from 47 countries, financial frictions are captured as the sensitivity of bond spreads to the issuing firms' financial leverage. This dynamic measure of financial frictions provides new insights into three characteristics of financial frictions. 1) In contrast to the inferences from widely-used measures, financial frictions display a large degree of variability, and have decreased over time. 2) The effect of financial frictions on private credit supply has decreased both in significance and magnitude over time. 3) Bankruptcy reforms, in general have not been effective in improving creditor/borrower rights.
\end{abstract}

Journal of Economic Literature Classification: G15; K22; O75

Keywords: financial frictions, leverage sensitivity, financial accelerator, bond deals. 


\section{Introduction}

After Chapter 11 was adopted in the United States in 1978, countries worldwide have reevaluated their mechanisms for conflict resolution and company reorganization in bankruptcy. Ensuing reforms and amendments of the bankruptcy procedures have attempted to improve the existing systems. These efforts, initially more prevalent in developed countries, later became more common in developing countries as well (especially after the crisis episodes of the 1990's, and higher capital market integration following the liberalization of financial markets). By design, these reforms and amendments have had important implications for creditor rights and the overall efficiency of bankruptcy proceedings (some improving, some deteriorating).

Widely-used measures of these financial frictions, however, show remarkable stability. For example, a well-known measure of creditor rights constructed by La Porta, Lopez-de-Silanes, Shleifer, and Vishny (1998) (hereafter, LLSV) indicates that credit rights have not changed for 110 countries out of the 133 in between 1978 and 2003. Although, the creditor rights index of LLSV is computed according to the rights defined in laws and regulations and does not reflect the effectiveness of actual insolvency practices, some survey-based measures of financial frictions (e.g. Djankov et al. 2008) indicate that creditor rights have not changed significantly in practice either. Naturally, studies (c.f. Djankov et al. 2007, 2008; La Porta, 2008; La Porta, Lopez-de-Silanes, Shleifer, 2008) that use these indicators do not find any evidence for convergence in financial frictions across countries. These findings, however, present a contrast to the findings in the comparative law literature. A majority of the studies in this literature finds that countries have adopted international best practices and implemented these laws more effectively parallel to the sharp increase in the volume of cross country trade and capital flows 
observed in the past 3 decades. ${ }^{1}$ Therefore, it is important to develop alternative methodologies that can account for these transitions in the world and are more efficient in determining how financial frictions have evolved over time. Identifying trends in financial frictions would be important for understanding not only the long-run but also the short-run performance of economies. While, it is well-established (c.f. Levine, 1999; North, 1982) that financial frictions and the quality of more broad institutions are key determinants of the cross-country differences in credit supply and long-run economic performance, more recent evidence (c.f. Acemoglu, Johnson, and Robinson, 2003; Aghion et al., 2004; Ranciere et al, 2008; Schneider and Tornell, 2004) indicates that the quality of institutions is also related to short-run dynamics such as the vulnerability to sudden reversals of capital flows and external shocks in general.

In this paper, I develop a new methodology to measure financial frictions. The main appeal of this methodology is that it presents a more dynamic approach to capturing trends in financial frictions compared to categorical (based on bankruptcy codes) and survey based measures by using continuous data to estimate financial frictions. The empirical methodology is motivated by theoretical frameworks characterized by asymmetric information and costly state verification (dating back to Akerloff, 1970). Specifically, these models predict that if the asymmetric information is between a lender and a borrower, financial frictions (state verification costs) generate a wedge between borrowing funds externally and raising funds internally. This wedge depends on how leveraged the borrower is and the level of financial frictions. A more subtle theoretical result, critical for the methodology developed in this paper, is that the sensitivity of borrowing costs to firms' financial leverage, or leverage sensitivity (hereafter, $L S$ )

\footnotetext{
${ }^{1}$ Although convergence in laws and regulations (and their implementation) is a widespread observation, (c.f. Cappelletti, 1989; Clark et al. 1994; Del Duca, 2007; Kotz and Zweigert 1998; Markesinis, 1994; Mattei, 1997; Schlesinger et al., 1998; Zekoll, 2006; Zuckerman, 1999) it should be noted that there are studies that find evidence against convergence (c.f. Juenger, 1997; Kerameus, 1997; Legrand, 1996).
} 
is positively related to the level of financial frictions. The intuition is that in a country with good creditor rights, a lender is more likely to recover a large percentage of its bad loans in a short period of time, and thus, financial leverage would not be as important for external finance premiums compared to a country with poor creditor rights. I use this theoretical prediction to capture financial frictions across countries.

To closely match theory, I use firm-level bond deals information from 47 countries, and estimate the sensitivity of corporate bond spreads to firms' financial leverage (LS). I estimate $L S$ by controlling for some of the economy-specific and bond-specific variables commonly used in the extensive strand of literature on the determinants of corporate bond spreads. Initial findings show that financial frictions measured by $L S$ are positively correlated with the other measures of financial frictions. The low levels of correlations, however, suggest that a large amount of variation in $L S$ is independent of the other measures. Moreover, I find that the variation in $L S$ is considerably larger than the variation in the other measures of financial frictions.

I proceed by testing whether this high, independent variation in $L S$ provides new insights into some of the characteristics of financial frictions. To do so, I use LS in a second stage to answer 3 questions: 1) Are financial frictions stable over time? 2) Do financial frictions affect private credit negatively? 3) Are bankruptcy reforms effective? Using LS, I find that financial frictions, in contrast to the usual finding, are not stable and exhibit a downward trend. Consistent with this, I find that countries' financial frictions are converging over time. The speed of convergence in the EU (European Union) member countries is relatively faster. Next, I find that the importance of financial frictions as a determinant of private credit, although significant in the whole sample period, has declined considerably over time both in significance and magnitude. This new insight is a unique contribution of this paper since using continuous data to estimate 
financial frictions allows me to more effectively capture the evolution of the relationship between financial frictions and private credit supply. Finally, I identify 13 comprehensive bankruptcy reform episodes to determine whether bankruptcy reforms reduce financial frictions. Consistent with anecdotal and empirical evidence, changes in $L S$ indicate that the bankruptcy reforms of Argentina and Mexico have been the most successful. Other reform episodes are found to have had smaller and/or insignificant effects on financial frictions.

The next section provides a discussion of the theoretical framework that motivates the empirical analysis. Section 3 describes how $L S$ is constructed. Section 4 answers the 3 questions mentioned above using LS. Section 5 concludes.

\section{Theoretical Framework}

Following the breakthrough studies on asymmetric information led by Akerlof (1970), a large number of studies have investigated the role that financial frictions play in determining the relationship between nominal and real variables in the economy. A subset of these studies (Bernanke, Gertler and Gilchrist, 1999; Carlstrom and Fuerst, 1997; Prescott and Townsend, 1984; Townsend, 1979) model frictions as the state-verification costs banks face when they agree on a loan contract. These costs represent the percentage of the value of a loan banks cannot recover when there is default. For example, Bernanke, Gertler and Gilchrist (1999) include these costs into an otherwise standard dynamic new Keynesian model to find the following positive relationship between the external finance premiums (difference between external and internal borrowing costs) firms pay and their financial leverage:

$$
\frac{E\left[R_{t}{ }^{k}\right]}{R_{t}}=v\left(\frac{Q_{t-1} K_{t}}{N_{t}}, \mu\right) \quad v^{\prime}\left(\frac{Q_{t-1} K_{t}}{N_{t}}\right)>0 \quad, \quad v^{\prime}(\mu)>0
$$


where $E\left[R_{t}{ }^{k}\right], R_{t}, Q_{t-1}, K_{t}, N_{t}$ and $\mu$ represent the borrowers' expected returns to capital, the risk free rate, price of capital, capital stock, the borrower's net worth, and the monitoring cost coefficient respectively. The monitoring costs (the costs incurred if there is default on the loan) are the state verification costs that represent financial frictions. Since borrowers (entrepreneurs) purchase their entire capital stock every period, $Q K$ in equation (1) represents investment expenditures and $Q K / N$ represents borrowers' leverage. External finance premium in this setup is approximated by the difference between expected returns to capital and the risk free rate, $E\left[R^{k}\right] / R$. Moreover, equation (1) shows that the positive relationship between leverage and external finance premium is stronger when financial frictions are higher.

Another characteristic of the optimality condition displayed in equation (1) is that external finance premiums are more sensitive to firms' leverage when financial frictions are high. This is a more subtle relationship in the model and can be seen more clearly if we linearize equation (1) as:

$\tilde{E F P} P_{t}=\alpha_{1}(\mu) \tilde{L E} V_{t}$

where $\alpha_{1}^{\prime}(\mu)>0, \tilde{E F} P_{t}=\tilde{R_{t}^{k}}-\tilde{R_{t}}, \tilde{L E} V_{t}=\tilde{Q}_{t-1}+\tilde{K}_{t}-\tilde{N}_{t}$, where “ $\sim$ " denotes percent deviation from steady state. Equation (4) shows that as the level of financial frictions $(\mu)$ increases, the external finance premium becomes more sensitive to firms' leverage. The reason is that when bankruptcy costs are low, creditors are not as affected by bankruptcy since they can retrieve a greater portion of a bankrupt firm's assets. In this case, the risk free rate is a relatively more important determinant of external finance rates. In contrast, when bankruptcy costs are high, leverage plays a more predominant role. 
Frameworks with costly state verification, therefore, predict that as the level of financial frictions increase, the external finance premium becomes more sensitive to firm leverage, i.e. leverage sensitivity increases. One can therefore, use leverage sensitivity as an indicator of financial frictions. In the next section, I proceed by approximating the level of financial frictions across countries using an empirical model that is motivated by the predictions of theory discussed above.

\section{Leverage Sensitivity as a Proxy for Financial Frictions}

\section{Measuring Leverage Sensitivity}

In this sub-section I estimate leverage sensitivity for each country. To capture leverage sensitivity, I estimate, using firm level data, the effect of firm leverage on its external finance premium. To do so, I approximate external finance premiums by corporate bond spreads (difference in yield between a corporate bond and a government bond with similar maturity). Of course, using firm-level data on the interest rates on bank loans would be a better way of matching the model described in the previous section. However, these data, to the best of my knowledge, are not available. Although there is evidence that the characteristics of firms that use bond finance versus those that use bank finance are different (c.f. Bolton and Freixas, 2000), to the extent that these asymmetries are similar across countries, bond spreads are reasonable proxies for external finance premiums.

To measure leverage sensitivity, I use data on non-financial firms' bond deals provided by the Thomson One Banker database. This database also provides some firm-specific and bondspecific variables that are widely-used in the literature. The panel data set is irregular, unbalanced and span the period January, 1995 to February, 2009. I chose this data range to 
maximize the number of observations and include as many countries as possible in the sample. There were 47 countries with sufficient data.

Using bond spreads to measure financial frictions is advantageous since there is a longstanding literature on the determinants of corporate bond spreads in both developing and advanced economies (c.f. Collin-Dufresne, Goldstein and Martin, 2001; for research focusing on the latter, and Cavallo and Valenzuela, 2007; Durbin and Ng, 2005 for studies on developing countries). To control for some of the well-established determinants of corporate bond spreads and identify the independent effects of firms' financial leverage on their bond spreads, I draw on this literature. The determinants of bond spreads in this literature roughly fall into 3 groups: 1) firm characteristics 2) bond characteristics and 3) macroeconomic conditions. I include these variables on the right hand side, to the extent that data are available, and estimate the following equation separately for each country:

$$
E \widetilde{F} P_{i t}=\gamma_{0 k}+\gamma_{1 k} L \widetilde{E} V_{i t-1}+\xi_{1 k} y_{i t-1}+\xi_{2 k} B C_{i t}+\xi_{3 k} M C_{t k}+\xi_{5 k} T_{k}+\xi_{6 k} I_{k}+v_{i t}
$$

where subscripts $i, k$ and $t$ denote the bond deal, the country and the time period. $E \widetilde{F} P_{i t}$ denotes the spread on the bonds issued by firm $i$ and $L \widetilde{E} V_{i t-1}$ is the financial leverage of this firm. $y_{i}$, $B C_{i t}$ and $M C_{t k}$ are vectors of firm-specific, bond-specific and macroeconomic indicators respectively. The variable definitions are provided in Appendix A. In addition to these variables, I also include annual time dummies and industry dummies denoted by $T_{k}$ and $I_{k}$ respectively. The coefficient of interest in equation (3) is $\gamma_{1 k}$. The estimated value of this coefficient captures the degree of financial frictions (or the sensitivity of bond spreads to leverage) in country $i$.

To measure corporate bond spreads, I follow the standard practice in the literature and compute $E \widetilde{F} P_{i t}$ as the difference between the yields of corporate bonds and government bonds of 
closest maturity. ${ }^{2}$ Let $Y T M_{t, T}^{i}$ and $Y T M_{t, T}^{g}$ denote the yield to maturity at time $t$ of corporate and government bonds that mature at time $T$ respectively, corporate bond spreads can be expressed as:

$$
E \widetilde{F} P_{i t}=Y T M_{t, T}^{i}-Y T M_{t, T}^{g}
$$

The sample includes bonds that are denominated in both local and foreign currency. If a 5 year Brazilian bond was denominated in dollars for example, I used the yield on a 5-year US treasury bond when measuring the spread. Alternatively, I considered only local currency denominated bonds. Despite decreasing the number of countries with sufficient observations, this alteration did not change the results significantly. The database has several ratios that can approximate the financial leverage variable $L \widetilde{E} V_{i t}$ such as, Total Debt/Equity, Total Debt/Market Capitalization, Proceeds/Equity. I used the Total debt/Equity ratio since data availability was the highest for this variable. ${ }^{3}$ To reduce the risk of reverse causality, I use the financial leverage data that were reported prior to the issue date.

Recent research finds, among the 3 sets of determinants of corporate bond spreads mentioned above, that firm-specific characteristics explain the largest portion of variation in corporate bond spreads (c.f. Cavallo and Valenzuela, 2007). Therefore, in addition to financial leverage, I include the well-known (c.f. Altman, 2000) firm-specific variables in equation (3). These variables are: return on assets, earnings before interest/assets and liquidity measured by the current ratio. In addition to these more common right hand side variables, I also account for the size of the firm. It is well-established that (c.f. Gertler and Gilchrist, 1993) borrowing constraints (such as that given by equation (1)) are more binding for smaller firms. Therefore,

\footnotetext{
${ }^{2}$ The main reason for using yield to maturity was the availability of data. There is research, however, that highlight the limitations of using this variable. For example, Cavallo and Valenzuela (2007) argue that it is very difficult, especially in developing countries, to find bonds of similar maturity and/or to determine maturity when there are contingent cash flows. The authors use option-adjusted spreads from Bloomberg to make bond spreads more comparable. In the estimation I only use bonds that don't have contingent cash flows due to such features as put or call options. Therefore, using yield to maturity is not unreasonable.

${ }^{3}$ I obtained very similar results using the other measures. The tables and a discussion of the results are available upon request.
} 
controlling for size is critical to measuring the effects of leverage that are independent of size.

Size is measured by the total assets of a firm (prior to the issue date) divided by the average total assets of firms in the country. 4,5

To capture the non-default component of corporate bond spreads, I include issue size, time to maturity and credit rating as bond-characteristics on the right hand side of equation (3). Although, other bond and bond/stock market characteristics have been used as explanatory variables, this data was not available for all the countries in the sample and therefore are excluded for consistency. ${ }^{6}$ Nevertheless, the 3 variables I include are more commonly used and have been effective in explaining the variation in bond spreads. Issue size are included since they are an indicator of bond liquidity and are, in general, found to be negatively related to bond spreads (c.f. Chacko et al., 2009). Time to maturity is included since longer time to maturity is associated with more risk and thus higher corporate bond spreads. Moreover, there is evidence that the relationship between leverage and corporate bond spreads is considerably different for different maturity groups. Specifically, the impact of changes in financial leverage on bond spreads is found to be higher for bonds with shorter maturity (c.f. Collin-Dufresne, Goldstein and Martin, 2001; Merton, 1974). Therefore, it is important to account for the maturity of the bond. Credit ratings have recently been excluded from the traditional models of credit risk. The main reason is that the changes in credit ratings are fully anticipated by investors and therefore do not affect bond spreads. Unlike these models, I focus on the cross-section variation in corporate bond spreads in this paper and not the variations over time. Although, changes in credit ratings may not affect bond spreads over time, there is a clear difference in bond spreads and the effect of

\footnotetext{
${ }^{4}$ Total assets are converted to real dollars when calculating the size measure.

${ }^{5}$ Additionally, I accounted for the openness of the firm (foreign sales/total sales) and tried different ratios that proxy liquidity, debt structure and profitability. The results were robust to these alterations.

${ }^{6}$ Some of these variables are: the presence or absence of put/call options, subordination, option-adjusted spreads and the probability of a jump in the stock market index.
} 
leverage on bond spreads across different rating groups (c.f. Collin-Dufresne, Goldstein and Martin, 2001). Thus, I include a measure for the credit rating of the bond (described in Appendix A) in equation (3).

Although equation (3) is measured by country, macroeconomic indicators such as the GDP growth rate, inflation and the external balance are included to measure the asymmetric effects that these variables may have across firms. Annual time dummies are included to capture the developments in the economy that are not accounted for by the macroeconomic variables. The non-standard variables in equation (3) are the industry dummies denoted by $I_{k}$. I include this variable given the evidence that there are significant differences --considerably larger than cross country differences-- in the transmission of monetary policy (thus, the effect of monetary policy on bond spreads) across industries (c.f. Dedola and Lippi, 2005).

\section{Findings}

Table 1 reports the leverage sensitivities that were estimated using equation (3) in each country. Countries are sorted by the size of their leverage sensitivities (highest to lowest). Equation (3) is estimated using OLS with robust standard errors. The coefficients of the control variables have the expected signs (except for a few countries) and are not reported for brevity. ${ }^{7}$ The first column in the table lists the number of bond deals that were reported in each country during the sample period. The second column displays the number of non-government bond deals for which I could find sufficient firm-specific data to estimate equation (3). ${ }^{8}$ As expected, the third column mostly reveals a positive relationship (except for Colombia) between leverage and corporate bond spreads and that these coefficients are highly significant for a majority of the countries ( 40 out of 47 countries). Results indicate that changes in leverage have a considerable

\footnotetext{
${ }^{7}$ The tables and a discussion of the results are available upon request.

${ }^{8}$ For the U.S. there were 269,902 non-government bond deals in the sample period. To simplify the analysis, I chose 10 percent of the deals by random draw.
} 
effect on corporate bond spreads. The magnitude of the coefficient implies that a 1 percent increase in leverage is associated with a 0.25 percent increase in bond spreads on average. This result is parallel to the recent findings of other studies (Cavallo and Valenzuela, 2007; CollinDufresne Goldstein and Martin, 2001; Durbin and Ng, 2005; Tang and Yan, 2008) and clearly suggests that financial leverage is a key determinant of corporate bond spreads. ${ }^{9}$ It is important to note that although countries with the highest (lowest) leverage sensitivities tend to have low (high) levels of GDP/Capita, the correlation between the two variables seems to be less than perfect. $^{10,11}$

Table 2 confirms this observation. Although the correlation between LS and GDP/Capita is negative, the correlation is not high. ${ }^{12}$ The table also compares $L S$ with other measures for financial frictions. Among these, the creditor rights index (CR) of LLSV (1998) is the most widely-used measure. The index captures the rights of secured lenders that are defined in laws and regulations and ranges from 0 (weak creditor rights) to 4 (strong creditor rights). $C R$ is available annually for the 1978-2003 period. The 3 other measures are survey based and are constructed by Djankov et al. (2008). Although more recent (available annually for the 20032008 period), these measures are included since they more closely match the financial frictions in the theoretical framework discussed above. In particular, the recovery rate variable $(R R$, averaged over 2004-2008) measures the cents on the dollar recouped by creditors through the bankruptcy or insolvency proceedings thus represents the empirical counterpart of the monitoring cost parameter defined in Section 2. The cost measure (cost, averaged over 2004-

\footnotetext{
${ }^{9}$ Unlike the analysis in this paper, a majority of these studies investigate the effects of changes in leverage on the changes in bond spreads over time. Nevertheless, the large magnitude of the leverage coefficient found in these studies implies that leverage is an important determinant of bond spreads.

${ }^{10} \mathrm{GDP} / \mathrm{Capita}$ is measured in constant dollars and is averaged over the 1995-2007 period.

${ }^{11}$ The GDP/Capita levels of the top 5 countries (with highest leverage sensitivities) are below the mean value of GDP/Capita in the sample and 4 out of the 5 countries with the lowest levels of leverage sensitivities have GDP/Capita's above the mean.

${ }^{12}$ Note that the standard errors of LS (computed by estimating equation (3)) are taken into account when measuring the standard deviation of $L S$ and its correlation with the other measures.
} 
2008) unlike recovery rates does not account for the duration of bankruptcy proceedings and measures costs incurred during bankruptcy proceedings as a percentage of the estate's value. To consider only the duration of the proceedings, I also include the variable Incdays (averaged over 2003-2008) which measures the number of days to resolve a payment dispute through courts. The correlation matrix indicates that $L S$, as predicted by theory, is positively related to financial frictions measured by other measures of financial frictions. Nevertheless, there is a large amount of variation in $L S$ that is independent of the other measures.

The low correlation of $L S$ and $C R$ as well as the low correlation of $C R$ with the other measures of financial frictions is also observed in Table 3. The countries in the table are sorted based on their $C R$ score (highest to lowest) and then by lncdays. The table shows that for some countries with high (low) $C R$ scores $L S$ is high (low) and that a similar dissimilarity is observed between $C R$, Incdays, cost and $R R$. For example, for the 6 out of 9 countries with strongest creditor rights (high $C R$ ) the average duration of court proceedings was above the mean. In the next section, I investigate whether the independent variation in $L S$ can provide more insights into some of the characteristics of financial frictions.

\section{The new measure for financial frictions and some common questions}

In this section, I investigate whether one can learn more about the characteristics of financial frictions by using LS. In so doing, I attempt to answer 3 common questions about the properties of financial frictions by using $L S, C R, R R$, cost and Incdays, and compare the conclusions. Although the literature on financial frictions is extensive, I identified the following 3 questions that were widely-studied and are also more relevant for understanding cross-country income differences: Are financial frictions stable over time? How do financial frictions affect private credit? How effective are bankruptcy reforms? 


\section{Are financial frictions stable over time?}

One key property of financial frictions measured by the $C R$ variable is that they are remarkably stable over time (c.f. Djankov et al., 2008). This stability is also observed in the survey based measures although they are available for a shorter period of time. The stability suggested by these measures is consistent with the common finding that other measures of institutional frameworks (such as corruption, government quality, measures of law and order traditions) have not changed significantly over time (c.f. Acemoglu, Johnson, and Robinson, $2001,2002)$. Table 4 displays this low variability of $C R, R R$, Incdays and cost for the countries in the sample and compares these with the variation in $L S$. The variations in $C R$ and $L S$ are measured for the 1978-2003 and 1995-2008 periods respectively. The variations in RR, Incdays and cost are measured for the 2004-2008 period. The unit-free measure of variability (coefficient of variation, CV) is used for comparison. It is clear from the table that $L S$ displays more variability. In fact, a majority of the observations for $C R$, Incdays and cost display no variation within the sample period. Although, the $\mathrm{CV}$ for $R R$ is non-zero for a majority of the countries it is considerably lower than in $L S$. Note that, restricting the sample to compare the variation of $L S$ and the other measures using the same time periods was immaterial to the conclusions.

One valid objection to the analysis so far could be that the high level of variation in $L S$ is generated spuriously by the methodology (using bond market data). Moreover, if $L S$ measures do not display a tendency to increase or decrease and if the differences in $L S$ across countries remain the same over time, the spurious variability in $L S$ would not provide any new insights. Therefore, it is critical to understand how the new measure of financial frictions has evolved over time and whether it points to trends in financial frictions. Uncovering these trends would also 
have implications for income differences in the world, as the qualities of institutions (such as the level of financial frictions) have been linked to growth performances.

To investigate the evolution of financial frictions, I divide the sample up into the 4 subperiods and measure LS separately in each sub-period. The number of sub-periods was determined by data availability. Specifically, when $L S$ was measured annually, standard errors of the LS coefficient for most developing countries were large mainly due to insufficient observations. Thus, when measuring variability among countries, the weights given to developing country observations were considerably small. ${ }^{13}$ For consistency, I use the same subperiods in the rest of the paper. To determine whether $L S$ displays a general trend in financial frictions, I compute, in each sub-period, the average value of $L S$ across countries. ${ }^{14}$ Moreover, I classify the countries as advanced, EU and developing to investigate the trends in financial frictions for different groups of countries. ${ }^{15}$ The results displayed in the top panel of Table 5 demonstrate a decline in the average levels of financial frictions over time. This decline is observed for each country group and the $t$-statistics that test whether the average level of $L S$ is significantly lower than the average level of $L S$ in the previous period indicate that the decline is significant. When measuring the $t$-statistics, the standard errors of $L S$ (computed by estimating equation (3)) were taken into account. The decrease in $L S$ was especially strong for EU countries in the last two sub-periods. Although the average level of $L S$ decreased 40 percent over the sample period, the gap between advanced and developing has not decreased. The results in the bottom panel of Table 5 indicate that differences across countries have also narrowed during the sample period. The numbers represent the standard deviations of $L S$, and the F-statistics indicate

\footnotetext{
${ }^{13}$ Although, the downward trend in $L S$ was less apparent for some countries, using 2 or 3 sub-periods revealed similar results.

${ }^{14}$ The $L S$ values are computed for each country by estimating equation (3) and using the observations in the sub-period. These values are used to compute the mean.

${ }^{15}$ Economies are separated into these groups according to the classification in International Monetary Fund's World Economic Outlook Report, April 2009. All of the countries included in the EU category were members of the European Union throughout the whole sample period.
} 
that the decrease in the standard deviations is significant in general. Similarly, the standard errors of $L S$ measured by estimating equation (3) were taken into account when computing the standard deviations and the F-statistics in Table 5. The decrease in variation across countries, similar to the average level of $L S$, was the strongest after 2002 and in the EU countries.

Overall, the results obtained by using $L S$ suggest that although differences in the quality of more broad institutions may not be diminishing, there is a tendency for convergence in one aspect of institutions (financial frictions). Of course, this conclusion is limited to the countries in the sample. On one hand, if data were available for less developed nations, the results perhaps would indicate that financial frictions have not decreased. On the other hand, one could argue that since $L S$ is available mostly for high income nations with developed financial markets, the decrease in frictions is not different from the convergence found among economies at similar stages of development. Nevertheless, it is important to note that the sample of countries includes 20 developing/emerging and 27 advanced economies, thus giving a considerable weight to both groups.

\section{Do financial frictions affect private credit negatively?}

One channel through which the quality of institutions has affected growth rates is credit supply. Indeed, the low qualities of institutions such as poor contract enforcement and creditor rights have been argued to depress the supply of credit and thus economic growth rates in less developed economies. In general, studies (c.f. Djankov et al, 2008; LLSV, 1998; Levine, 1999) have used long periods of time and measures based on the codes of law (similar to CR) to analyze the relationship credit supply and financial frictions (one aspect of institutional quality). Using shorter periods of time would not be expected to produce different results given the remarkable stability in these measures of creditor rights. Therefore, given the evidence for a 
decline and a convergence in the levels of financial frictions, it is a natural next step to determine whether the new measure for financial frictions $(L S)$ provides different insights into the relationship between financial frictions and credit supply, especially into how this relationship has evolved over time.

In this section, I reinvestigate this relationship by estimating the following model:

$$
c r \_g d p_{i}=\alpha_{0} f f_{i}+\alpha_{1} x_{i}+e_{i}
$$

where $c r \_g d p_{i}, f f_{i}$ and $x_{i}$ denote the credit to GDP ratio, the measures for financial frictions and a vector of control variables for country $i$ respectively.

I begin by estimating the model using the variables and the data in Djankov et al. (2008). In their baseline model, the authors use $C R$ and Incdays as proxies for financial frictions, and their sample includes 129 countries. Replicating their results provides a basis of comparison and helps to determine whether one can draw different inferences from the model by using $L S$. To reproduce their results, I use OLS (with robust standard errors) as an estimation strategy and choose the following variables and sample period: The dependent variable is the private credit to GDP, averaged over 1999-2003. The independent variables of main interest are CR (as of 1999) and Incdays (as of 2003). The control variables include, the logarithm of gross national income (GDP) averaged over 2001-2003, GDP per capita growth rate, averaged over 1979-2003, and inflation measured by the GDP deflator (avginf), averaged over 1999-2003. ${ }^{16}$ The definitions of the data are reproduced in Appendix A.

The first column of Table 6 presents the results. The results are identical to Djankov et al. (2008) and indicate that in countries with high financial frictions, lenders are less willing to

\footnotetext{
${ }^{16} \mathrm{GDP}$ is included to account for the fixed institutional costs associated with the efficient functioning of credit markets and the fact that these costs are only affordable for large economies. GDP per capita is included because faster growing economies could have more demand for credit. Inflation is included to account for the effects it could have on the value of outstanding stock of debt.
} 
extend credit. The control variables enter with theoretically predicted signs. ${ }^{17}$ I proceed by estimating equation (5) using $L S$ to capture the degree of financial frictions. To do so, I compute LS over 1995-2003. It is important to note that using the coefficients of leverage estimated in the previous section (LS) in equation (5) without considering their standard deviations may lead to invalid inferences. To deal with this problem (more commonly known as the generated regressors problem), I account for the measurement error in $L S$ and adjust the standard errors of the coefficients in equation (5). ${ }^{18}$ The results are presented in the second column of Table 6. Although the relationship between financial frictions and credit supply is not as strong as in the baseline model, the coefficient of $L S$ is significant and indicates a negative relationship between financial frictions and credit supply. The magnitude of the coefficient indicates that if the sensitivity of bond spreads to financial leverage by 1 percent, credit to GDP ratio decreases by 0.35 percentage points. The rest of the coefficients have the same signs. It is important to note that the strong relationship found in the baseline model may be partially due to the higher number of countries (129). Moreover, since the sample includes less developed countries whose quality of institutions presents a sharp contrast to those of other countries, this strong relationship is not unexpected. However, when I reestimate the baseline model by only using data from the 47 countries with $L S$ measures, I find that the coefficients of $C R$ and Incdays are still significant. These results are displayed in the third column of Table 6 and suggest that the weaker relationship between $L S$ and credit to GDP is not due to sample selection. I also consider $R R$ (as of 2004) as an alternative measure for financial frictions and find that the coefficient of $R R$ is significant regardless of the number of countries in the sample. These results are displayed in the last two columns of Table 6.

\footnotetext{
${ }^{17}$ See Djankov et al. (2008) for a discussion of how the right hand side variables are related to the amount of credit supply.

${ }^{18}$ The methodology I follow is similar to that of Gawande (1997).
} 
For consistency, I compute the variables over the periods used in Djankov et al. (2007). A possible objection to the methodology so far, however, could be that the financial friction measures are endogenous. Indeed, $L S, C R$, Incdays and $R R$ are measured over periods that overlap the period that credit to GDP variable is measured in. The fact that CR, LS and Incdays are fairly constant over time and that they thereby, provide an exogenous source of variation in credit supply across countries decreases the risks of simultaneity. Nevertheless, I also used legal origins as instruments for $C R, R R$ and lncdays and computed $L S$ and $C R$ as averages over 19951998 and 1978-1998 (preceding the period credit to GDP is measured in) respectively. The results were unchanged by these alterations and are not reported for brevity. ${ }^{19}$

\section{$\underline{\text { Sub-periods }}$}

To analyze how the relationship between financial frictions and credit supply has evolved over time, I estimate equation (5) for the 4 sub-periods used in the previous section. Table 7 presents the results. One important observation is the decrease in both the significance and the magnitude of the $L S$ coefficient over time. This is in contrast to the increase in the significance and the magnitude of the GDP per capita coefficient over the same time period. The rest of the coefficients have the expected signs. The first observation suggests that financial frictions are not as effective in explaining cross country differences in credit supply as they were 15 years ago. However, the increase in the GDP per capita coefficient implies that there may not be a convergence in the amount of credit supply (as a \% of GDP) of advanced and developing

\footnotetext{
${ }^{19}$ I also included country-specific variables to account for the prevalence of small firms in the economy. As mentioned above, small firms are more likely to be credit constrained and thus, the effect of financial frictions on credit supply could be higher in economies with many small firms. I used 2 indicators to account for small firm presence: 1) the percent of firms using banks to finance investment, with higher values suggesting more small firms 2) stock market capitalization as a \% of GDP. Results did not change considerably: $L S$ had a significant effect on credit supply independent of each indicator. Nevertheless, the interaction variables $L S^{*}$ (small firm presence) implied that the relationship between $L S$ and credit supply was stronger in countries with more small firm presence.
} 
economies. This lack of convergence is observed in Figure $1 .{ }^{20}$ Although explaining this observation is not the main objective of this paper, results in Table 7 indicate that financial frictions may not be the culprit.

\section{Are bankruptcy reforms effective?}

Parallel to the globalization of financial markets, countries have updated/overhauled their bankruptcy codes to adapt to the current business environment. The bankruptcy reforms have in general aimed to simplify the codes, mirror modern bankruptcy laws, protect creditor rights and/or provide more flexibility for debtors that are in financial distress. It is therefore, interesting to investigate whether the new measure, constructed in this paper, detects a decrease (or an increase) in financial frictions after the laws were put into effect.

In my sample and for the countries in this sample, I identified 13 comprehensive bankruptcy reform acts that are argued to be a considerable improvement over the existing laws governing bankruptcy proceedings for businesses. These reforms are listed with a brief description in Appendix B. Of course, within the sample period countries have had other reforms or amendments that lowered financial frictions. These reforms were not included either because they were related to laws governing consumers or they were not as comprehensive.

It is important to note at this point that the improved legal conditions (especially for creditors) promised by the new laws have not always come to fruition due to poor implementation. ${ }^{21}$ It is, therefore, unreasonable to expect $L S$ to detect a change in financial

\footnotetext{
${ }^{20}$ The figure graphs the ratios of net domestic credit to GDP ratios for advanced and developing economies. I consider both the developing countries in the baseline sample (developing47) and in the Djankov et al. (2007) sample (developing 129). Ratios are computed as simple averages for each year for each different country group. The figure demonstrates that, in fact there is a divergence in credit supply across advanced and developing countries.

${ }^{21}$ For a majority of the countries, the evidence for successful implementation is mixed at best. See Dewaelheyns and Van Hulle (2009) for Belgium; Acerbi, Felsberg, Kargman (2006), Locatelli (2008) for Brazil; Falke, (2007), Qi (2008) for China; Davydenko, Franks (2008), Eger (2001), Herrmann and Keppel (2005) for Germany; Carter (2000), Lubben and Moore (2009) for Indonesia and Thailand; American Bankruptcy Institute (2002), Anderson (2001), Abe (2000), Teikoku Data Bank. Special Project (2005), for Japan; Koh (2007) for Korea; Thompson (2003), Mogilianskya, Konstantin and Zhuravskaya (2007) for Russia; Gutiérrez, Olalla and Olmo (2007) for Spain.
} 
frictions after each of the 13 reform episodes. Nevertheless, there is sufficient research and anecdotal evidence that allows me to identify successful reform episodes. This evidence indicates that reform acts of Argentina and Mexico have been relatively successful in increasing creditor rights and in decreasing the duration of bankruptcy proceedings. ${ }^{22}$

For these 13 countries, I measure LS before and after the reform act was put into effect. For consistency, I measure LS 3 years before and after the reform episode. ${ }^{23}$ Results are displayed in Table 8. The third column reports the change in $L S$ and reveals, consistent with the anecdotal and empirical evidence that financial frictions have decreased significantly in Argentina and Mexico. The magnitude of the drop in LS is considerably larger than those of other countries. It is important note that during the same time period $C R$ does not predict an improvement in creditor rights. This maybe partially explained by the fact that $C R$, by construction, does not take account of the shortening in the duration of the bankruptcy proceedings. However, the main reason for the different conclusions drawn from the two measures can be partially explained by the fact that $C R$, unlike $L S$, does not consider how effectively the laws and regulations were implemented. Other than Argentina and Mexico, $L S$ has changed significantly after the reform episodes only in Germany, Japan and Spain. This is consistent with the evidence suggesting that a majority of the reform episodes have not significantly affected financial frictions. Note however, that for 10 out of the 13 countries the coefficient was negative, consistent with the negative trend in financial frictions found above. The divergence in conclusions drawn from the analysis with $L S$ and $C R$ is also observed in China, Germany, Indonesia, Japan, Russia and Thailand. For example, the $C R$ measure predicts an

\footnotetext{
22 c.f. Graham-Canedo (2007), Lubben and Moore (2009), Sheppard (2001), Good (2008) for Mexico, and Laguna (2003) and World Bank (2002) for Argentina.

${ }^{23}$ Alternatively, a 1 and 2 year window for all countries and a 4 year window was used for Japan and Germany but results were very similar. Note also that none of the countries experienced a different reform episode during 3 years after or preceding the bankruptcy reforms displayed in Table 8 .
} 
improvement in creditor rights in China and Russia. Conversely, LS predicts that creditor rights have not changed significantly in these countries, suggesting that actual implementation has not been effective. The changes in other measures of financial frictions during the sample period was only available for 5 countries and do not provide any different insights.

Note that using more formal tests to detect structural breaks would be a better way of capturing the effects of bankruptcy reforms. However, the frequency of LS data needed to effectively measure structural breaks was only available for a few countries and these tests could not be used. Albeit, the results suggest that comprehensive bankruptcy reforms may not be the reason for the negative trend in financial frictions.

\section{Conclusion}

In this paper I constructed a new measure for financial frictions (LS). LS captures financial frictions as the leverage sensitivity of corporate bond spreads. This is consistent with one optimality condition of recent costly-state-verification models that indicates a positive relationship between financial frictions and leverage sensitivity. The main appeal of the methodology is that it uses financial market data and offers a more dynamic approach to measuring financial frictions compared with more common methodologies that use surveys or categorical data. Using this new measure, I found that the degree of financial frictions has decreased and converged across countries, the effect of financial frictions on private credit has decreased both in magnitude and significance and that in general bankruptcy reforms have not been successful in changing the level of financial frictions.

These different and additional insights into the characteristics of financial frictions underscore the importance of developing more dynamic, financial data-based methods for measuring financial frictions. Uncovering the dynamics governing financial frictions using these 
models would especially help to measure the persistence of financial frictions and to understand how one key determinant of cross-country differences in growth rates and income is evolving over time.

Although, the results clearly suggest that financial frictions have decreased over time. More powerful tests to support this observation and to understand if the negative trend was stronger in some periods could not be performed because the necessary data required for these tests were not available for a majority of the countries. Nevertheless, as capital markets integrate and the number of bond deals increase (especially in developing countries), this analysis can be conducted for shorter sub-periods and for more countries and thereby would facilitate a greater understanding of financial frictions.

\section{References}

Abe, Shinichiro, 2000. The New Japanese Reorganization and Rehabilitation Law. The American Bar Association, Business Law Section, Spring.

Acemoglu, Daron, Johnson, Simon, Robinson James A., 2001. The Colonial Origins of Comparative Development: An Empirical Investigation. American Economic Review, 91, 1369-1401.

2002. Reversal of Fortune: Geography and Institutions in the Making of the Modern World Income Distribution. Quarterly Journal of Economics, 117, 1231-1294.

2003. Institutional Causes, Macroeeconomic Symptoms: Volatility, Crises and Growth. Journal of Monetary Economics, 50, 49-123.

Acerbi, Andrea, Felsberg, Thomas, B., Kargman, Steven, 2006. Brazil overhauls restructuring regime. International Financial Law Review, page 1.

Aghion, Philippe, Bacchetta, Philippe, and Banerjee, Abhijit, 2004. Financial development and the instability of open economies. Journal of Monetary Economics, 51, 1077-1106.

Akerlof, George A., 1970. The Market for 'Lemons': Quality Uncertainty and the Market Mechanism. The Quarterly Journal of Economics, 84(3), 488-500.

Altman, Edward, 2000. Predicting Financial Distress of Companies: Revisiting the Z-score and Zeta Models. Working Paper. New York, United States: New York University, Stern School of Business.

American Bankruptcy Institute, 2002. Corporate/Debt Restructuring: Japan, the Hong Kong SAR and the People's Republic of China: A Roundtable Discussion. American Bankruptcy Institute Law Review 10, 1.

Anderson, Kent, 2001. Small Businesses Reorganizations: An Examination of Japan's Civil Rehabilitation Act Considering Policy Implications and Foreign Creditor's Practical Interests. American Bankruptcy Law Journal, 75, 355. 
Bernanke, Ben S., Gertler, Mark, Gilchrist, Simon, 1999. The Financial Accelerator in a Quantitative Business Cycle Framework. Handbook of Macroeconomics, 1341-93.North Holland.

Bolton, Patrick, Freixas, Xavier, 2000. Equity, Bonds and Bank Debt: Capital Structure and Financial Market Equilibrium under Asymmetric Information. Journal of Political Economy, 108, 324-351.

Cappelletti, Mauro, 1989. The Judicial Process in Comparative Perspective. Oxford: Clarendon Press, New York: Oxford University Press.

Carlstrom, Charles T., Fuerst, Timothy S., 1997. Agency Costs, Net Worth, and Business Fluctuations: A Computable General Equilibrium Analysis. American Economic Review, 87, 893-910.

Carter, Courtney C., 2000. Saving Face in Southeast Asia: The Implementation of Prepackaged Plans of Reorganization in Thailand, Malaysia, and Indonesia. Bankruptcy Developments Journal, 17(0), 295-999.

Cavallo, Eduardo A., Valenzuela, Patricio, 2007. The Determinants of Corporate Risk in Emerging Markets: An Option-Adjusted Spread Analysis. IMF Working Papers 07/228.

Chacko, George, Mahanti, Sriketan, Mallik Gaurav, Subrahmanyam, Marti G., 2009. Latent liquidity: A new measure of liquidity with an application to corporate bonds. Journal of Financial Economics, forthcoming.

Clark, David S., Haley, John O., Merryman, John H., 1994. The Civil Law Tradition: Europe, Latin America, and East Asia. Charlottesville, VA, Michie Co.

Collin-Dufresne, Pierre, Goldstein, Robert S., Martin, Spencer J., 2001. The determinants of credit spread changes. Journal of Finance, 56, 2177-2207.

Davydenko, Sergei A., Franks, Julian, 2008. Do Bankruptcy Codes Matter? A Study of Defaults in France, Germany, and the U.K. Journal of Finance, 63(2), 565-608.

Dedola, Luca, Lippi, Francesco, 2005. The monetary transmission mechanism: Evidence from the industries of five OECD countries. European Economic Review, 49(6), 1543-1569.

Del Duca, Louis F., 2007. Developing Global Transnational Harmonization Procedures for the Twenty-First Century: The Accelerating Pace of Common and Civil Law Convergence. Texas International Law Journal, 42(3), 625-60.

Dewaelheyns, Nico, Van Hulle, Cynthia, 2009. Bankruptcy reform - evidence from a survey among judges and receivers. Applied Economics Letters, forthcoming.

Djankov, Simeon, Hart, Oliver, McLiesh, Caralee, Shleifer, Andrei, 2008. Debt Enforcement around the World. Journal of Political Economy, 116(6), 1105-1149.

Djankov, Simeon, McLiesh, Caralee, Shleifer, Andrei, 2007. Private credit in 129 countries. Journal of Financial Economics 84, 299-329.

Durbin, Erik, Ng, David, 2005. The sovereign ceiling and emerging market corporate bond spreads. Journal of International Money and Finance, 24(4), 631-649.

Eger, Thomas, 2001. Bankruptcy Regulations and the New German Insolvency Law from an Economic Point of View. European Journal of Law and Economics, 11(1).

Falke, Mike, 2007. China's New Law on Enterprise Bankruptcy: A Story With a Happy End? International Insolvency Review, 16(1) 63-74.

Gawande, Kishore, 1997. Generated regressors in linear and nonlinear models. Economics Letters, 54(2), 119-126. 
Gertler, Mark, Gilchrist, Simon, 1993. The Role of Credit Market Imperfections in the Monetary Transmission Mechanism: Arguments and Evidence. The Scandinavian Journal of Economics, 95(1), 43-64.

Good, Michael D., 2008. More, Better, Faster: Gauging the Effectiveness of Mexican Insolvency Reform. International Corporate Rescue, 5(5), 293-300.

Graham-Canedo, Jonatan, 2007. Comparative Analysis Of Bankruptcy Legal Provisions From Mexico And The United States: Which Legal System Is More Attractive? DePaul Business \& Commercial Law Journal, 6(1), 19-28.

Gutiérrez, Carlos L., Olalla, Myriam, G., Olmo, Begoña T., 2007. Financial Consequences of the Bankruptcy Law: European Comparison. Revista de Contabilidad- Spanish Accounting Review, 9(18), 111-143.

Herrmann, Martin, Keppel, Michael, 2005. Germany Slow to Embrace New Bankruptcy Code. Journal of Corporate Renewal, February Issue.

International Monetary Fund, 2009. World Economic Outlook Report, April 2009.

Juenger, Friederich K., 1997. Some Comments on European Procedural Harmonization. The American Journal of Comparative Law, 45(4), 931-937.

Kerameus, Konstantinos, 1997. Political Integration and Procedural Convergence in the European Union. The American Journal of Comparative Law, 45(4), 919-930.

Koh, Harold H., 2007. Korea's Newly Enacted Unified Bankruptcy Act: The Role Of The New Act In Facilitating (Or Discouraging) The Transfer Of Corporate Control. UCLA Pacific Basin Law Journal, 24(2), 201-224.

Kotz, Hein, Zweigert, Konrad, 1998. Introduction to Comparative Law. Oxford: Clarendon Press.

La Porta, Rafael, Lopez-de-Silanes, Florencio, Vishny, Robert, Shleifer, Andrei, 1998. Law and Finance. Journal of Political Economy, 106, 1113-1155.

La Porta, Rafael, Lopez-de-Silanes, Florencio, Shleifer, Andrei, 2008. The Economic Consequences of Legal Origins. Journal of Economic Literature, 46(2), 285-332.

La Porta, Rafael, 2008. The Divergence of Legal Procedures. American Economic Journal:Economic Policy, forthcoming.

Laguna, Francisco A., 2003. Bankruptcy Law in Argentina: practice and procedure. Business Credit, 105(4), 47-54.

Lambert-Mogiliansky, Ariane, Sonin, Konstantin, Zhuravskaya, Ekaterina, 2007. Are Russian commercial courts biased? Evidence from a bankruptcy law transplant. Journal of Comparative Economics, 35, 254-277.

Legrand, Pierre, 1996. European Legal Systems Are Not Converging. The International and Comparative Law Quarterly, 45(1), 52-81.

Levine, Ross, 1999. Law, Finance, and Economic Growth. Journal of Financial Intermediation, 8, $8-35$.

Locatelli, Fernando, 2008. International Trade and Insolvency Law: Is the UNCITRAL Model Law on Cross-Border Insolvency an Answer for Brazil? (An Economic Analysis of its Benefits on International Trade). Law and Business Review of the Americas, 14(2), 313-345.

Lubben, Stephen, Moore, Daniel J., 2009. Financial Distress in Emerging Markets, in Financial Innovations in Emerging Markets, Greg N. Gregoriou ed. Chapman-Hall /Taylor and Francis, forthcoming.

Markesinis, Basil S., 1994. Learning from Europe and Learning in Europe. In the Gradual Convergence: Foreign Ideas, Foreign Influences, and English Law on the Eve of the 21st Century, ed. Basil S. Markesinis. Oxford: Clarendon Press. 
Mattei, Ugo. 1997. Comparative Law and Economics. The University of Michigan Press.

Merton, Robert C., 1974. On the pricing of corporate debt: The risk structure of interest rates. Journal of Finance, 29, 449-470.

North, Douglass C., 1982. Structure and Change in Economic History. Norton, New York.

Prescott, Edward C., Townsend, Robert M., 1984. General Competitive Analysis in an Economy with Private Information. International Economic Review, 25(1), 1-20.

Qi, Lijie, 2008. The Corporate Reorganization Regime under China's New Enterprise. Bankruptcy Law. International Insolvency Review, 17(1), 13-32.

Rancière, Roman, Tornell, Aaron, Westermann, Frank, 2008. Systemic Crises and Growth. The Quarterly Journal of Economics, 123(1), 359-406.

Schlesinger, Rudolf B., Baade, Hans W., Herzog, Peter E., Wise, Edward M., 1998. Comparative Law: Cases, Texts, Materials. 6th edition. New York: Foundation Press.

Schneider, Martin, Tornell, Aaron, 2004. Balance Sheet Effects, Bailout Guarantees and Financial Crises. Review of Economic Studies, 71, 883-913.

Sheppard, Hale E., 2001. The New Mexican Insolvency Law: Policy Justifications for U.S. Assistance. UCLA Journal of International Law and Foreign Affairs, 6(1) 45-87.

Tang, Dragon Y., Yan, Hong, 2008. Liquidity and Credit Default Swap Spreads. EFA 2008 Athens Meetings Paper.

Teikoku Databank special project, 2005. Survey on Trends in Civil Rehabilitation Law Application Days.

Thompson, W., 2003. Reforming Russian bankruptcy law. International Company and Commercial Law Review, 154-162.

Townsend, Robert M., 1979. Optimal contracts and competitive markets with costly state verification. Journal of Economic Theory, 21(2), 265-293.

World Bank, 2002. Report On Observance Of Standards \& Codes: Argentina, Insolvency And Creditor Rights Systems.

Zekoll, Joachim, 2006. Comparative Civil Procedure. In The Oxford Handbook of Comparative Law, ed. Mathias Reimann and Reinhard Zimmermann. Oxford and New York: Oxford University Press.

Zuckerman, Adrian A. S., 1999. The Dimensions of Civil Justice. In Civil Justice in Crisis: Comparative Perspectives of Civil Procedure, ed. Adrian A. S. Zuckerman. Oxford and New York: Oxford University Press. 
Appendix A: Data Summary

Table A1: Variables and Data Sources

\begin{tabular}{|c|c|}
\hline Variable & Description and Source \\
\hline \multicolumn{2}{|l|}{ Bond Characteristics } \\
\hline Yield to maturity & $\begin{array}{l}\text { This is the rate of return an investor will receive if the security is held to the } \\
\text { first maturity date. Source: Thomson One Banker. }\end{array}$ \\
\hline Issue size & $\begin{array}{l}\text { Principal amount of the issue plus overallotment amount sold in all markets } \\
\text { (Host mil). Source: Thomson One Banker. }\end{array}$ \\
\hline Rating & $\begin{array}{l}\text { High Yield Flag (Y/N): A Y/N flag indicating whether the deal is considered } \\
\text { Leveraged/ High Yield or Non Leveraged. High yield is defined for bonds and } \\
\text { preferred securities as issues having a Standard \& Poor's rating of BB+ and } \\
\text { below or a Moody's rating of Ba1 and below. All leveraged and highly } \\
\text { leveraged loans are covered under the high yield flag option. Loan Yield Types } \\
\text { are defined as follows: (IG=Investment Grade, NG=Near Investment Grade, } \\
\text { LV=Leveraged, HL=Highly Leveraged). Source: Thomson One Banker. }\end{array}$ \\
\hline Years to maturity & $\begin{array}{l}\text { Number of years from the offer date to the maturity date. Source: Thomson One } \\
\text { Banker. }\end{array}$ \\
\hline
\end{tabular}

Firm Characteristics

Total Debt/Equity ratio

Return on Assets

Earnings before interest and taxes

depreciation and amortization /Assets ratio

Current Ratio

Industry classification

Macroeconomic Variables - Equation (3)

GDP growth rate

External balance

Inflation

Total debt (short term, long term, subordinated and convertible) divided by total equity prior to the offering. Source: Thomson One Banker.

Net income after taxes / Assets. Source: Thomson One Banker.

Earnings before interest and taxes depreciation and amortization / Total Assets. Source: Source: Thomson One Banker.

Total Current Assets divided by the Total Current Liabilities. Source: Thomson One Banker.

Thomson Financial proprietary macro-level industry classifications based on SIC Codes, NAIC Codes and overall company business description. There are 14 macro-level classifications

y-o-y \% change in real GDP measured in the quarter that bonds were issued. Source: IFS.

The balance of exports f.o.b. and imports f.o.b. Source: IFS.

y-o-y \% change in the Consumer Price Indices measured in the month that bonds were issued. Source: IFS.

Measures of financial frictions

Creditor rights

Recovery rate

An index aggregating creditor rights, following La Porta et al. (1998). A score of one is assigned when each of the following rights of secured lenders is defined in laws and regulations: First, there are restrictions, such as creditor consent or minimum dividends, for a debtor to file for reorganization. Second, secured creditors are able to seize their collateral after the reorganization petition is approved, i.e. there is no "automatic stay" or "asset freeze." Third, secured creditors are paid first out of the proceeds of liquidating a bankrupt firm, as opposed to other creditors such as government or workers. Finally, if management does not retain administration of its property pending the resolution of the reorganization. The index ranges from 0 (weak creditor rights) to 4 (strong creditor rights). Source: Djankov, McLiesh and Shleifer (2006).

The recovery rate is recorded as cents on the dollar recouped by creditors through the bankruptcy or insolvency proceedings. The calculation takes into account whether the business emerges from the proceedings as a going concern as well as costs and the loss in value due to the time spent closing down. If the business keeps operating, no value is lost on the initial claim, set at 100 cents on the dollar. If it does not, the initial 100 cents on the dollar are reduced to 70 cents on the dollar. Then the official costs of the insolvency procedure are deducted ( 1 cent for each percentage of the initial value). Finally, the value lost as a result of the time the money remains tied up in insolvency proceedings is taken into account, including the loss of value due to depreciation of the hotel furniture. Consistent with international accounting practice, the depreciation rate for furniture is taken to be $20 \%$. The furniture is assumed to account for a quarter of the total value of assets. The recovery rate is the present value of the remaining proceeds, based on end-2006 lending rates from the International Monetary Fund's International Financial Statistics, supplemented with data from central banks. Annually available for the 2004-2009 period. Source: World Bank Doing Business database. 
Cost $\%$ of estate

Lncdays

Macroeconomic Variables - Equation (5)

Private Credit/GDP

GDP

GDP per capita growth

Avginf
The cost of the bankruptcy proceedings as a percentage of the estate's value The cost is calculated on the basis of survey responses by insolvency practitioners and includes court fees as well as fees of nsolvency practitioners, independent assessors, lawyers and accountants. Respondents provide cost estimates from among the following options: less than $2 \%, 2-5 \%, 5-8 \%, 8$ $11 \%, 11-18 \%, 18-25 \%, 25-33 \%, 33-50 \%, 50-75 \%$ and more than $75 \%$ of the value of the business estate. Annually available for the 2004-2009 period. Source: World Bank Doing Business database.

The number of days to resolve a payment dispute through courts. The data are based on the methodology in Djankov et al. (2003) and describe the number of calendar days to enforce a contract of unpaid debt worth $50 \%$ of the country's GDP per capita. Annually available for the 2004-2009 period. Source: World Bank Doing Business database.

Ratio of credit from deposit taking financial institutions to the private sector (IFS lines 22d and 42d) relative to GDP (IFS line 99b). Line 22d measures claims on the private sector by commercial banks and other financial institutions that accept transferable deposits such as demand deposits. Line 42d measures claims on the private sector given by other financial institutions that do not accept transferable deposits but that perform financial intermediation by accepting other types of deposits or close substitutes for deposits (e.g. savings and mortgage institutions, post office savings institutions, building and loan associations, certain finance companies, development banks and offshore banking institutions). Source: IMF International Financial Statistics database. Logarithm of gross national product (current U.S. Dollars), average 1999-2003. Source: World Development Indicators 2005.

Average annual growth in gross domestic product per capita from 1979 - 2003. Source: World Development Indicators 2005.

Annual percentage inflation, GDP deflator, average 1999-2003. Source: World Development Indicators 2004. 
Appendix B: Bankruptcy/Insolvency Reforms

\begin{tabular}{|c|c|c|}
\hline country & date in effect & Description \\
\hline Argentina & May-02 & $\begin{array}{l}\text { Required by the International Monetary Fund's (IMF) in order to resume giving the country financial assistance. Central } \\
\text { aspect:allows creditors to take the control of a company in bankruptcy using the "unavoidable capitalization" figure. }\end{array}$ \\
\hline Belgium & Jan-98 & $\begin{array}{l}\text { Replaces existing rules dating back to } 1853 \text {. Encourages corporate rehabilitation. A company that is granted } \\
\text { reorganization protection receives creditor protection for up to } 6 \text { months. Introduces an early warning system for financial } \\
\text { distress.A number of adjustments to the liquidation procedure are introduced to reduce the occurrence of domino effects, i.e., } \\
\text { when suppliers are thrown into financial distress due to the bankruptcy of their clients. }\end{array}$ \\
\hline Brazil & Jun-05 & $\begin{array}{l}\text { Provides enhanced protections and flexibility for debtors in financial distress to reorganize while continuing to operate their } \\
\text { businesses. At the same time, creditors, and particularly secured creditors, are likely to see their debt recovery prospects } \\
\text { improved when businesses are liquidated, giving them a more significant role in the negotiation of restructuring plans and } \\
\text { in reorganization proceedings than under the previous bankruptcy law. }\end{array}$ \\
\hline China & Jun-07 & $\begin{array}{l}\text { China's new bankruptcy law has a much broader application and it mirrors the modern bankruptcy laws of other countries, } \\
\text { particularly the United States. The new law applies to Chinese companies operating overseas and it applies to foreign } \\
\text { companies operating in China. The law utilizes an administrator who will act much like bankruptcy trustees do in U.S. } \\
\text { bankruptcy proceedings. The administrator's role is to help the creditors and to assist in assuring the bankruptcy runs } \\
\text { smoothly. The most important difference between China's new and old bankruptcy laws is that the new law gives secured } \\
\text { claims priority over employee, tax, and general claims, unlike the old law which gave workers (it was communism, } \\
\text { remember) first claim to the debtor's assets. The new law is more in line with most developed commercial countries in that } \\
\text { employee claims now take precedence only over unsecured creditors. }\end{array}$ \\
\hline Germany & Jan-99 & $\begin{array}{l}\text { Replaces the three Insolvency Laws which had been in force, ie the "Konkursordnung" (Bankruptcy Law), the } \\
\text { Vergleichsordnung" (Composition Law) and the "Gesamtvollstreckungsordnung" (Common Execution Law). that were less } \\
\text { suitable to solve the legal, economic and social problems arising out of the breakdown of a company in an appropriate } \\
\text { manner. The new Insolvency law standardizes insolvency proceedings. Purpose is to jointly satisfy all creditors of a debtor } \\
\text { out of the available assets. The new law enables the creditors to decide whether the company may operate further after } \\
\text { restructuring or whether only a liquidation of the company appears reasonable. }\end{array}$ \\
\hline Indonesia & Aug-98 & $\begin{array}{l}\text { The New Bankruptcy Law seeks to overcome the reluctance of creditors and debtors to use statutory remedies in order to } \\
\text { resolve debt problems. The New Bankruptcy Law provides for 'a definite time frame for decision making on a declaration of } \\
\text { bankruptcy' which is aimed at speeding up bankruptcy proceedings, and interim actions with respect to the debtor's estate, } \\
\text { which should be useful for creditors concerned about dilution of the debtor's assets before a declaration of bankruptcy.The } \\
\text { expansion of the professional group known as kuratur ('receivers') and the establishment of a new Commercial Court is } \\
\text { aimed to improve the efficiency and credibility of bankruptcy proceedings. }\end{array}$ \\
\hline Italy & Jan-08 & $\begin{array}{l}\text { The comprehensive bankruptcy reform redefines the scope of bankruptcy proceedings from punishing the debtor to satisfying } \\
\text { creditors; allows the bankrupt business' operations to continue; simplifies the liquidation of the assets and the distribution of } \\
\text { the proceeds among the creditors. }\end{array}$ \\
\hline Japan & Apr- 00 & $\begin{array}{l}\text { The Civil Rehabilitation Law allows each creditor to enforce its rights under continuing court supervision of the turnaround } \\
\text { plan. The law deals with a provision of a second rehabilitation law, kaisha seiri that required complete or nearly unanimous } \\
\text { approval by creditors of a reorganization plan. With the removal of the many institutional barriers to an effective corporate } \\
\text { reorganization process, Japan's new bankruptcy regulatory regime accelerates the restructuring of the businesses. The new } \\
\text { law replaces the Composition Law (Wagi h } \tilde{A}^{\prime} \text { Law , 1922). }\end{array}$ \\
\hline Korea, South & Apr-06 & $\begin{array}{l}\text { Debtor Rehabilitation and Bankruptcy Act (the DRBA) allows the creditors meeting to be convened even in bankruptcy } \\
\text { proceedings and enhances creditor protection by conferring a greater level of authority to the creditors meeting.Regulations } \\
\text { on corporate reorganization, which originally applied to limited liability companies (chusik hoesa), will apply to all debtors. } \\
\text { The DRBA brings early rehabilitation for insolvent companies. Overall the implementation of the DRBA enhances the } \\
\text { efficiency of the rehabilitation and bankruptcy proceedings and provide effective and equitable remedies for creditors. }\end{array}$ \\
\hline Mexico & May-00 & $\begin{array}{l}\text { Mexico's new bankruptcy law, codified as the Ley de Concursos Mercantiles (LCM") incorporates the best international } \\
\text { practices. The LCM was enacted partly in response to the need for better protection of the rights of creditors. It confers } \\
\text { original and exclusive jurisdiction over bankruptcy cases and proceedings arising under such cases to the federal district } \\
\text { court judges. It creates the Federal Institute of Bankruptcy Specialists which is responsible for supervising the bankruptcy } \\
\text { administrators establishing adequate rules of bankruptcy procedure and resolving extrajudicial processes affecting } \\
\text { bankruptcy cases. It facilitates the timely and transparent administration and disposition of the property of the bankruptcy } \\
\text { estate wherever located. It provides equal access to the court and participation in the distribution of the estate to both local } \\
\text { and foreign creditors. It facilitates international cooperation between the Mexican bankruptcy courts and foreign courts. }\end{array}$ \\
\hline Russia & Dec-02 & $\begin{array}{l}\text { Bankruptcy act } 2002 \text { aims to prevent the business of making money by forcing companies into bankruptcy. It is designed to } \\
\text { encourage "civilized bankruptcy procedures". It balances the interests of creditors, shareholders and management. The law } \\
\text { protects firms from creditors with bad intentions. External managers will be subjected to criminal sanctions for inappropriate } \\
\text { handling of bankruptcy procedures. The new law to protects companies from unscrupulous bankruptcy proceeding behavior. }\end{array}$ \\
\hline Spain & Sep-04 & $\begin{array}{l}\text { The aim of the new Act is to modernize the Spanish bankruptcy law. The bankruptcy proceedings have been simplified. The } \\
\text { new Act contemplates a singleinsolvency proceeding, which is simply called "bankruptcy" (concurso de acreedores) and is } \\
\text { applicable to all sort of debtors (legal entities and individuals).This proceeding can conclude either with the approval of the } \\
\text { settlement of creditors or with the liquidation of the company. }\end{array}$ \\
\hline Thailand & Feb-99 & $\begin{array}{l}\text { The Act for the Establishment of and Procedure for Bankruptcy Court improves implementation of the law.The law creates } \\
\text { an organization better trained than the existing civil courts to handle the complicated financial and management issues } \\
\text { associated with bankruptcy. The Act streamlines legal proceedings. Tthe Bankruptcy Court proceeds with the trial of a case } \\
\text { consecutively without adjournment until completion thereof unless there is unavoidable necessity. This change is a major } \\
\text { improvement over the existing civil court procedures that } \\
\text { allowed bankruptcy cases to drag on for years. }\end{array}$ \\
\hline
\end{tabular}

Notes: The table provides a brief summary of the bankruptcy reform episodes for each country included in Section 4 (subsection: How effective are bankruptcy reforms?). 
Table 1: Estimation results --Equation (3)

\begin{tabular}{|c|c|c|c|c|c|c|c|}
\hline & NOBS & In the sample & $\hat{\gamma}_{1 k}$ & $\hat{\sigma}_{\gamma_{1 k}}$ & t-stats & R-Squared & $\begin{array}{l}\text { GDP/Capita } \\
(1995-2007) \\
\end{array}$ \\
\hline Indonesia & 667 & 497 & 1.31 & 0.12 & 11.25 & 0.48 & 873.77 \\
\hline Peru & 1020 & 529 & 0.84 & 0.28 & 2.99 & 0.41 & $2,199.54$ \\
\hline Philippines & 583 & 398 & 0.63 & 0.13 & 4.72 & 0.36 & $1,027.77$ \\
\hline Malaysia & 1965 & 1647 & 0.53 & 0.04 & 13.48 & 0.34 & $4,166.00$ \\
\hline Argentina & 1242 & 730 & 0.52 & 0.05 & 10.09 & 0.90 & $7,747.46$ \\
\hline Hong Kong & 3425 & 1800 & 0.48 & 0.02 & 21.18 & 0.97 & $26,788.85$ \\
\hline Venezuela & 242 & 114 & 0.46 & 0.02 & 22.95 & 0.90 & $4,929.31$ \\
\hline Turkey & 217 & 146 & 0.40 & 0.29 & 1.39 & 0.01 & $4,104.85$ \\
\hline Portugal & 846 & 175 & 0.37 & 0.05 & 6.83 & 0.92 & $10,678.69$ \\
\hline Korea, South & 18138 & 8542 & 0.37 & 0.08 & 4.53 & 0.58 & $11,474.62$ \\
\hline Norway & 1306 & 716 & 0.36 & 0.02 & 17.54 & 0.73 & $37,721.62$ \\
\hline Belgium & 698 & 324 & 0.35 & 0.06 & 5.55 & 0.79 & $22,510.77$ \\
\hline Austria & 1707 & 1142 & 0.34 & 0.02 & 14.98 & 0.52 & $23,947.31$ \\
\hline Finland & 963 & 653 & 0.28 & 0.04 & 7.84 & 0.55 & $23,706.54$ \\
\hline Greece & 367 & 149 & 0.28 & 0.57 & 0.48 & 0.91 & $12,176.62$ \\
\hline Sweden & 2534 & 1439 & 0.27 & 0.02 & 13.86 & 0.56 & $27,869.92$ \\
\hline United States & 40424 & 17269 & 0.23 & 0.00 & 56.48 & 0.38 & $34,381.23$ \\
\hline Germany & 16052 & 9111 & 0.22 & 0.01 & 28.81 & 0.40 & $22,923.31$ \\
\hline Russia & 398 & 290 & 0.21 & 0.11 & 1.87 & 0.74 & $1,989.08$ \\
\hline Ireland & 4148 & 900 & 0.18 & 0.02 & 9.51 & 0.46 & $25,490.54$ \\
\hline Israel & 347 & 275 & 0.17 & 0.04 & 4.06 & 0.38 & $19,038.08$ \\
\hline Australia & 7514 & 3155 & 0.17 & 0.01 & 21.06 & 0.91 & $21,245.92$ \\
\hline China & 949 & 580 & 0.16 & 0.04 & 4.61 & 0.73 & $1,103.15$ \\
\hline Colombia & 1031 & 113 & -0.13 & 9.10 & -0.01 & 0.33 & $2,526.00$ \\
\hline Panama & 269 & 105 & 0.12 & 0.05 & 2.36 & 0.82 & $4,051.77$ \\
\hline Japan & 12225 & 9078 & 0.12 & 0.00 & 39.63 & 0.33 & $37,366.69$ \\
\hline Spain & 3051 & 986 & 0.12 & 0.02 & 6.22 & 0.36 & $14,397.62$ \\
\hline Canada & 8816 & 4636 & 0.11 & 0.01 & 15.86 & 0.92 & $23,384.46$ \\
\hline Italy & 3527 & 886 & 0.11 & 0.02 & 5.04 & 0.19 & $19,014.08$ \\
\hline United Kingdom & 17453 & 5555 & 0.10 & 0.01 & 14.32 & 0.38 & $24,968.00$ \\
\hline Puerto Rico & 688 & 508 & 0.10 & 0.04 & 2.48 & 0.89 & $8,098.23$ \\
\hline New Zealand & 447 & 201 & 0.09 & 0.19 & 0.49 & 0.38 & $13,608.23$ \\
\hline India & 3760 & 2921 & 0.09 & 0.02 & 5.49 & 0.69 & 492.31 \\
\hline Netherlands & 8349 & 4306 & 0.08 & 0.01 & 7.00 & 0.56 & $23,748.15$ \\
\hline Bolivia & 171 & 161 & 0.08 & 0.04 & 2.37 & 0.74 & $1,023.54$ \\
\hline Chile & 821 & 469 & 0.08 & 0.04 & 2.07 & 0.35 & $5,093.69$ \\
\hline Mexico & 1717 & 607 & 0.07 & 0.04 & 1.63 & 0.74 & $5,779.92$ \\
\hline Thailand & 961 & 687 & 0.06 & 0.02 & 3.22 & 0.32 & $2,226.69$ \\
\hline Brazil & 2130 & 699 & 0.06 & 0.01 & 4.23 & 0.91 & $3,783.54$ \\
\hline France & 7056 & 3799 & 0.06 & 0.01 & 9.03 & 0.92 & $22,342.08$ \\
\hline Taiwan & 3510 & 2573 & 0.05 & 0.01 & 8.51 & 0.24 & \\
\hline Luxembourg & 3859 & 3859 & 0.05 & 0.02 & 2.49 & 0.09 & $46,326.15$ \\
\hline Switzerland & 2000 & 1709 & 0.05 & 0.01 & 4.04 & 0.61 & $34,509.77$ \\
\hline Singapore & 1398 & 970 & 0.04 & 0.01 & 3.00 & 0.93 & $23,237.62$ \\
\hline Iceland & 314 & 79 & 0.04 & 0.23 & 0.16 & 0.39 & $31,522.15$ \\
\hline South Africa & 205 & 93 & 0.04 & 0.28 & 0.13 & 0.59 & $3,181.46$ \\
\hline Denmark & 1055 & 615 & 0.03 & 0.01 & 2.51 & 0.28 & $29,804.08$ \\
\hline
\end{tabular}

Notes: 1 . The table reports the results from the estimation of equation (3):

$E \widetilde{F} P_{i t}=\gamma_{0 k}+\gamma_{1 k} L \widetilde{E} V_{i t-1}+\xi_{1 k} y_{i t-1}+\xi_{2 k} B C_{i t}+\xi_{3 k} M C_{t k}+\xi_{5 k} T_{k}+\xi_{6 k} I_{k}+v_{i t}$

2. The first and second column display the number of bond deals that were available and that were used respectively. The third and fourth column displays the coefficients and the standard errors of the financial leverage variable respectively. Countries are sorted based on the size of their leverage coefficients (in a descending order). 
Table 2. Summary statistics and the correlation matrix

\begin{tabular}{lrrrrrr}
\hline & obs. & mean & median & s.d. & min. & max. \\
\hline$L S$ & 47 & 0.24 & 0.16 & 0.24 & 0.03 & 1.31 \\
$\log$ (gdp/cap) & 133 & 3.30 & 3.27 & 0.71 & 1.95 & 4.64 \\
CR & 133 & 1.80 & 2.00 & 1.14 & 0.00 & 4.00 \\
Incdays & 133 & 5.79 & 5.89 & 0.65 & 3.30 & 7.29 \\
$R R$ & 119 & 34.94 & 28.93 & 24.44 & 0.00 & 92.60 \\
cost (\% of estate) & 115 & 14.51 & 13.50 & 10.64 & 1.00 & 76.00 \\
\hline
\end{tabular}

Correlation Matrix

\begin{tabular}{|c|c|c|c|c|c|c|}
\hline & $L S$ & $\log (g d p / c a p)$ & $C R$ & Incdays & $R R$ & cost ( $\%$ of estate) \\
\hline$L S$ & 1 & & & & & \\
\hline $\log (g d p / c a p)$ & -0.38 & 1 & & & & \\
\hline$C R$ & -0.10 & 0.20 & 1 & & & \\
\hline Incdays & 0.30 & -0.53 & -0.24 & 1 & & \\
\hline$R R$ & -0.33 & 0.83 & 0.18 & -0.57 & 1 & \\
\hline cost ( $\%$ of estate) & 0.22 & -0.51 & 0.00 & 0.54 & -0.57 & 1 \\
\hline
\end{tabular}

Notes: 1 . The table compares provides summary statistics and a correlation matrix for the coefficients of the leverage variable in equation (3) (LS), GDP per capita and 4 other measures of financial frictions.

2. The standard errors of $L S$ (computed by estimating equation (3)) are taken into account when measuring the standard deviation of $L S$ and its correlation with the other measures. 
Table 3: Comparison of financial frictions

\begin{tabular}{|c|c|c|c|c|c|c|c|c|c|c|c|}
\hline & $L S$ & $C R$ & lncdays & $R R$ & $\cos t$ & & $L S$ & $C R$ & lncdays & $R R$ & $\operatorname{cost}$ \\
\hline Mean & 0.21 & 1.80 & 5.79 & 36.15 & 14.51 & Mean & 0.25 & 1.80 & 5.79 & 36.15 & 14.51 \\
\hline New Zealand & 0.09 & 4 & 3.91 & 77.92 & 4 & Cambodia & & 2 & 5.99 & & \\
\hline Nicaragua & & 4 & 5.04 & 33.72 & 15 & Egypt, Arab Rep. & & 2 & 6.02 & & \\
\hline Hong Kong, China & 0.48 & 4 & 5.35 & 80.23 & 9 & India & 0.09 & 2 & 6.05 & 12.02 & 9 \\
\hline United Kingdom & 0.10 & 4 & 5.66 & 70.83 & 6 & Bulgaria & & 2 & 6.09 & 33.28 & 9 \\
\hline Zimbabwe & & 4 & 5.86 & 1.62 & 22 & Sri Lanka & & 2 & 6.09 & 47.12 & 5 \\
\hline Panama & 0.12 & 4 & 5.87 & 31.87 & 18 & Honduras & & 2 & 6.30 & 19.13 & 15 \\
\hline Kenya & & 4 & 5.89 & 30.03 & 22 & Iran, Islamic Rep. & & 2 & 6.30 & & \\
\hline Lebanon & & 4 & 6.58 & 18.07 & 22 & Slovak Republic & & 2 & 6.34 & & \\
\hline Nigeria & & 4 & 6.59 & 26.98 & 22 & Indonesia & 1.31 & 2 & 6.35 & 11.95 & 18 \\
\hline Netherlands & 0.08 & 3 & 3.87 & 86.78 & 4 & Dominican Republic & & 2 & 6.36 & 6.93 & 38 \\
\hline Singapore & 0.04 & 3 & 4.23 & 91.30 & 1 & Mozambique & & 2 & 6.36 & 13.53 & 9 \\
\hline Korea, Rep. & 0.37 & 3 & 4.32 & & & Bolivia & 0.08 & 2 & 6.38 & 36.85 & 15 \\
\hline Denmark & 0.03 & 3 & 4.42 & 72.90 & 4 & United Arab Emirates & & 2 & 6.42 & 8.80 & 30 \\
\hline Botswana & & 3 & 5.04 & 56.97 & 15 & Serbia and Montenegro & & 2 & 6.94 & & \\
\hline Australia & 0.17 & 3 & 5.06 & 79.70 & 8 & Italy & 0.11 & 2 & 7.24 & 59.77 & 21 \\
\hline Germany & 0.22 & 3 & 5.21 & 53.95 & 6 & Greece & 0.28 & 1 & 5.02 & 45.07 & 9 \\
\hline Latvia & & 3 & 5.24 & 33.98 & 13 & Switzerland & 0.05 & 1 & 5.14 & 46.85 & 4 \\
\hline Azerbaijan & & 3 & 5.59 & 32.28 & 8 & Ghana & & 1 & 5.30 & 24.40 & 22 \\
\hline El Salvador & & 3 & 5.62 & 27.92 & 9 & Sweden & 0.27 & 1 & 5.34 & 75.62 & 9 \\
\hline South Africa & 0.04 & 3 & 5.62 & 32.70 & 18 & Ireland & 0.18 & 1 & 5.38 & 87.53 & 9 \\
\hline Czech Republic & & 3 & 5.70 & 18.45 & 16 & Finland & 0.28 & 1 & 5.48 & 88.32 & 4 \\
\hline Malaysia & 0.53 & 3 & 5.70 & 38.55 & 15 & Morocco & & 1 & 5.48 & 34.92 & 18 \\
\hline Bosnia and Herzegovina & & 3 & 5.80 & 33.95 & 9 & United States & 0.23 & 1 & 5.52 & 65.03 & 7 \\
\hline Saudi Arabia & & 3 & 5.89 & 28.72 & 22 & Puerto Rico & 0.10 & 1 & 5.60 & 58.25 & 8 \\
\hline Austria & 0.34 & 3 & 5.92 & 72.75 & 18 & Zambia & & 1 & 5.61 & 20.68 & 9 \\
\hline Albania & & 3 & 5.97 & & & Lesotho & & 1 & 5.65 & 34.35 & 8 \\
\hline Kuwait & & 3 & 5.97 & 36.23 & 1 & Paraguay & & 1 & 5.65 & 13.27 & 9 \\
\hline Croatia & & 3 & 6.03 & 29.23 & 15 & Papua New Guinea & & 1 & 5.69 & 23.02 & 23 \\
\hline Ethiopia & & 3 & 6.04 & 32.62 & 15 & Portugal & 0.37 & 1 & 5.77 & 73.25 & 9 \\
\hline Venezuela, RB & 0.46 & 3 & 6.10 & & & Jordan & & 1 & 5.83 & 27.28 & 9 \\
\hline Kyrgyz Republic & & 3 & 6.20 & 14.60 & 15 & Canada & 0.11 & 1 & 5.85 & 89.37 & 4 \\
\hline Macedonia, FYR & & 3 & 6.23 & 14.65 & 29 & Hungary & & 1 & 5.90 & 38.15 & 15 \\
\hline Israel & 0.17 & 3 & 6.37 & 41.57 & 23 & Philippines & 0.63 & 1 & 5.94 & 4.13 & 38 \\
\hline Uruguay & & 3 & 6.43 & 28.93 & 7 & Pakistan & & 1 & 5.98 & 39.78 & 4 \\
\hline Syrian Arab Republic & & 3 & 6.51 & & & Rwanda & & 1 & 5.98 & & \\
\hline Slovenia & & 3 & 6.91 & 44.17 & 8 & Vietnam & & 1 & 6.00 & 15.45 & 15 \\
\hline Angola & & 3 & 6.92 & & & Algeria & & 1 & 6.01 & 41.70 & \\
\hline Japan & 0.12 & 2 & 4.09 & 92.60 & 4 & Mauritania & & 1 & 6.02 & 9.12 & 9 \\
\hline Norway & 0.36 & 2 & 4.47 & 90.65 & 1 & Burundi & & 1 & 6.24 & & \\
\hline Belgium & 0.35 & 2 & 4.72 & 86.22 & 4 & Argentina & 0.52 & 1 & 6.25 & 30.42 & 14 \\
\hline Lithuania & & 2 & 5.04 & 46.92 & 10 & Costa Rica & & 1 & 6.31 & 19.72 & 15 \\
\hline Spain & 0.12 & 2 & 5.13 & 76.68 & 15 & Brazil & 0.06 & 1 & 6.34 & 7.43 & 11 \\
\hline Armenia & & 2 & 5.27 & 40.75 & 4 & Congo, Dem. Rep. & & 1 & 6.81 & 2.57 & 29 \\
\hline Jamaica & & 2 & 5.31 & 64.07 & 18 & Poland & & 1 & 6.91 & 27.43 & 22 \\
\hline Uganda & & 2 & 5.34 & 34.07 & 30 & Guatemala & & 1 & 7.29 & 27.43 & 15 \\
\hline Taiwan, China & 0.05 & 2 & 5.35 & 67.10 & 4 & Tunisia & & 0 & 3.30 & 42.93 & 7 \\
\hline China & 0.16 & 2 & 5.48 & 32.93 & 22 & France & 0.06 & 0 & 4.32 & 46.52 & 9 \\
\hline Tanzania & & 2 & 5.49 & 18.02 & 22 & Guinea & & 0 & 5.72 & 21.30 & 8 \\
\hline Belarus & & 2 & 5.52 & 24.72 & 22 & Niger & & 0 & 5.80 & 8.77 & 18 \\
\hline Ukraine & & 2 & 5.59 & 8.62 & 42 & Mali & & 0 & 5.83 & 14.78 & 18 \\
\hline Namibia & & 2 & 5.60 & 40.10 & 15 & Yemen, Rep. & & 0 & 5.89 & & \\
\hline Malawi & & 2 & 5.62 & 12.30 & 30 & Colombia & -0.13 & 0 & 5.89 & 55.77 & 1 \\
\hline Madagascar & & 2 & 5.63 & & & Ecuador & & 0 & 5.96 & 15.47 & 18 \\
\hline Moldova & & 2 & 5.63 & 28.27 & 9 & Mexico & 0.07 & 0 & 6.04 & 64.18 & 18 \\
\hline Chile & 0.08 & 2 & 5.72 & 21.80 & 16 & Peru & 0.84 & 0 & 6.09 & 28.07 & 7 \\
\hline Sierra Leone & & 2 & 5.72 & 8.92 & 42 & Lao PDR & & 0 & 6.09 & & \\
\hline Mongolia & & 2 & 5.75 & 18.40 & 8 & Oman & & 0 & 6.12 & 34.58 & 4 \\
\hline Russian Federation & 0.21 & 2 & 5.80 & 27.40 & 9 & Burkina Faso & & 0 & 6.13 & 16.17 & 9 \\
\hline Turkey & 0.40 & 2 & 5.80 & 13.62 & 15 & Senegal & & 0 & 6.18 & 22.75 & 7 \\
\hline Romania & & 2 & 5.81 & 18.27 & 9 & Cote d'Ivoire & & 0 & 6.26 & & \\
\hline Nepal & & 2 & 5.86 & 24.57 & 9 & Chad & & 0 & 6.27 & & \\
\hline Bangladesh & & 2 & 5.90 & 23.65 & 8 & Togo & & 0 & 6.28 & 18.57 & 15 \\
\hline Haiti & & 2 & 5.91 & 3.42 & 30 & Congo, Rep. & & 0 & 6.33 & 19.57 & 24 \\
\hline Uzbekistan & & 2 & 5.91 & 12.97 & 10 & Benin & & 0 & 6.35 & 13.83 & 16 \\
\hline Georgia & & 2 & 5.93 & 23.23 & 4 & Cameroon & & 0 & 6.37 & 24.27 & 15 \\
\hline Thailand & 0.06 & 2 & 5.97 & 35.63 & 36 & Central African Republic & & 0 & 6.49 & & 76 \\
\hline Kazakhstan & & 2 & 5.99 & 19.83 & 18 & & & & & & \\
\hline
\end{tabular}

Notes: The table compares the degree of financial frictions predicted by different measures. Countries are sorted based on the creditor rights index $(C R)$ (strongest creditor rights to weakest) then by the number of days to resolve a payment dispute through courts (Incdays) (lowest number of days to highest). 
Table 4. Stability of financial frictions

\begin{tabular}{|c|c|c|c|c|c|}
\hline & $L S$ & $C R$ & $R R$ & Time & Cost \\
\hline Argentina & 1.68 & 0 & 0.19 & 0 & 0.12 \\
\hline Australia & 0.26 & 0 & 0.01 & 0 & 0 \\
\hline Austria & 0.91 & 0 & 0.01 & 0 & 0 \\
\hline Belgium & 0.23 & 0 & 0.00 & 0 & 0 \\
\hline Bolivia & 0.21 & 0 & 0.04 & 0 & 0 \\
\hline Brazil & 0.73 & 0 & 1.08 & 0.47 & 0.16 \\
\hline Canada & 0.93 & 0 & 0.01 & 0 & 0 \\
\hline Chile & 1.48 & 0 & 0.09 & 0.12 & 0.10 \\
\hline China & 0.36 & 0 & 0.06 & 0.17 & 0 \\
\hline Colombia & 0.44 & 0 & 0.04 & 0 & 0 \\
\hline Denmark & 0.76 & 0 & 0.15 & 0.44 & 0 \\
\hline Finland & 1.16 & 0.27 & 0.01 & 0 & 0 \\
\hline France & 0.56 & 0 & 0.03 & 0 & 0 \\
\hline Germany & 1.43 & 0 & 0.04 & 0 & 0.64 \\
\hline Greece & 0.28 & 0 & 0.02 & 0 & 0 \\
\hline Hong Kong & 0.71 & 0 & 0.01 & 0 & 0 \\
\hline Iceland & 0.18 & 0 & 0.02 & 0 & 0 \\
\hline India & 1.45 & 0.12 & 0.08 & 0 & 0 \\
\hline Indonesia & 0.82 & 0.19 & 0.12 & 0.05 & 0 \\
\hline Ireland & 0.70 & 0 & 0.01 & 0 & 0 \\
\hline Israel & 0.73 & 0.13 & 0.09 & 0 & 0 \\
\hline Italy & 0.95 & 0 & 0.16 & 0.19 & 0.10 \\
\hline Japan & 0.38 & 0.16 & 0.00 & 0 & 0 \\
\hline Korea, South & 0.73 & 0 & 0.01 & 0 & 0 \\
\hline Luxembourg & 0.22 & na & 0.00 & 0 & 0 \\
\hline Malaysia & 0.19 & 0 & 0.01 & 0 & 0 \\
\hline Mexico & 0.67 & 0 & 0.02 & 0 & 0 \\
\hline Netherlands & 0.65 & 0 & 0.02 & 0 & 0 \\
\hline New Zealand & 0.70 & 0 & 0.02 & 0 & 0 \\
\hline Norway & 0.73 & 0 & 0.03 & 0 & 0 \\
\hline Panama & 1.22 & 0 & 0.02 & 0 & 0 \\
\hline Peru & 1.09 & 0 & 0.13 & 0 & 0 \\
\hline Philippines & 0.92 & 0 & 0.05 & 0 & 0 \\
\hline Portugal & 0.28 & 0 & 0.03 & 0 & 0 \\
\hline Puerto Rico & 0.33 & 0 & 0.06 & 0 & 0 \\
\hline Russia & 0.83 & 0.36 & 0.06 & 0 & 0 \\
\hline Singapore & 0.26 & 0 & 0.00 & 0 & 0 \\
\hline South Africa & 0.88 & 0 & 0.04 & 0 & 0 \\
\hline Spain & 0.62 & 0 & 0.02 & 0 & 0 \\
\hline Sweden & 0.60 & 0.28 & 0.04 & 0 & 0 \\
\hline Switzerland & 0.86 & 0 & 0.01 & 0 & 0 \\
\hline Thailand & 0.79 & 0.18 & 0.48 & 0 & 0 \\
\hline Turkey & 1.26 & 0 & 0.57 & 0 & 0 \\
\hline United Kingdom & 0.23 & 0 & 0.49 & 0 & 0 \\
\hline United States & 0.62 & 0 & 0.49 & 0 & 0 \\
\hline Venezuela & 0.75 & 0 & 0.51 & 0 & 0 \\
\hline
\end{tabular}

Notes: 1 . The table reports the coefficient of variation (CV) for each country. Annual observations are used to measure CV.

2. The standard errors of $L S$ computed by estimating equation (3) are taken into account when measuring CV for $L S$. 
Table 5. Trends and convergence in $L S$

\begin{tabular}{|c|c|c|c|c|c|}
\hline & & 1995-1997 & 1998-2001 & $2002-2005$ & 2006-2008 \\
\hline \multirow[t]{4}{*}{ Averages } & All Countries & 0.34 & $\begin{array}{r}0.28 \\
(1.42)\end{array}$ & $\begin{array}{r}0.23 \\
(1.73)^{*}\end{array}$ & $\begin{array}{r}0.16 \\
(2.71)^{* * *}\end{array}$ \\
\hline & Advanced (including EU) & 0.28 & $\begin{array}{r}0.21 \\
(1.75)^{*}\end{array}$ & $\begin{array}{r}0.17 \\
(1.56)\end{array}$ & $\begin{array}{r}0.09 \\
(3.51)^{* * * *}\end{array}$ \\
\hline & EU only & 0.29 & $\begin{array}{r}0.23 \\
(1.69)^{*}\end{array}$ & $\begin{array}{r}0.16 \\
(1.76)^{*}\end{array}$ & $\begin{array}{r}0.06 \\
(3.39)^{* * * *}\end{array}$ \\
\hline & Developing & 0.37 & $\begin{array}{r}0.31 \\
(1.89)^{*} \\
\end{array}$ & $\begin{array}{r}0.27 \\
(1.99)^{* *} \\
\end{array}$ & $\begin{array}{r}0.21 \\
(2.30)^{* *} \\
\end{array}$ \\
\hline \multirow[t]{4}{*}{ Standard Deviations } & All Countries & 0.49 & $\begin{array}{r}0.31 \\
(2.45)^{* * *}\end{array}$ & $\begin{array}{r}0.20 \\
(2.40)^{* * *}\end{array}$ & $\begin{array}{r}0.10 \\
(4.24)^{* * *}\end{array}$ \\
\hline & Advanced (including EU) & 0.25 & $\begin{array}{r}0.19 \\
(1.79)\end{array}$ & $\begin{array}{r}0.10 \\
(3.79)^{* * *}\end{array}$ & $\begin{array}{r}0.06 \\
(2.40)^{* *}\end{array}$ \\
\hline & EU only & 0.28 & $\begin{array}{r}0.21 \\
(1.81)\end{array}$ & $\begin{array}{r}0.09 \\
(4.86)^{* * *}\end{array}$ & $\begin{array}{r}0.05 \\
(3.66)^{* * * *}\end{array}$ \\
\hline & Developing & 0.45 & $\begin{array}{r}0.36 \\
(1.51)\end{array}$ & $\begin{array}{r}0.25 \\
(2.06)^{*}\end{array}$ & $\begin{array}{r}0.20 \\
(1.66)^{*}\end{array}$ \\
\hline
\end{tabular}

Notes: 1 . The top panel of Table 5 represents the mean values of $L S$ for 4 different country groups in 4 consecutive periods. Mean values are measured by computing the value of $L S$ in each country using the observations for the sub-period, and averaging these values across countries. The $t$-statistics below each coefficient are based on tests used to determine whether the average level of LS is significantly lower than the average level of $L S$ in the previous period.

2. The bottom panel of Table 5 measures the standard deviation of $L S$ across countries in each sub-period and $F$-statistics in parentheses are based on tests used to determine whether the standard deviation of $L S$ is significantly lower than its standard deviation in the previous period.

3. The standard errors of $L S$ computed by estimating equation (3) are taken into account when computing the $t$-statistics and $F$ statistics.

4. * significant at $10 \%$; ** significant at $5 \% ; * * *$ significant at $1 \%$. 
Table 6. Private credit and financial frictions - Equation (5)

\begin{tabular}{|c|c|c|c|c|c|}
\hline Dependent variable: Private Credit/GDP & Djankov et al. all countries & LS 47 countries & Djankov et al. 47 countries & RR-all countries & RR-47 countries \\
\hline GDP & $\begin{array}{c}10.816 \\
(1.254)^{* * *}\end{array}$ & $\begin{array}{c}7.560 \\
(3.641)^{* *}\end{array}$ & $\begin{array}{c}5.119 \\
(3.118)^{*}\end{array}$ & $\begin{array}{c}8.140 \\
(1.435)^{* * *}\end{array}$ & $\begin{array}{c}2.272 \\
(3.563)\end{array}$ \\
\hline GDP per capita growth & $\begin{array}{c}1.976 \\
(1.081)^{*}\end{array}$ & $\begin{array}{c}8.403 \\
(3.255)^{* * *}\end{array}$ & $\begin{array}{c}5.168 \\
(3.068)^{*}\end{array}$ & $\begin{array}{c}1.150 \\
(0.746)\end{array}$ & $\begin{array}{c}6.186 \\
(2.955)^{* *}\end{array}$ \\
\hline avginf & $\begin{array}{l}-0.093 \\
(0.061)\end{array}$ & $\begin{array}{l}-0.472 \\
(0.368)\end{array}$ & $\begin{array}{l}-0.279 \\
(0.353)\end{array}$ & $\begin{array}{l}-0.062 \\
(0.062)\end{array}$ & $\begin{array}{l}-0.171 \\
(0.269)\end{array}$ \\
\hline Incdays & $\begin{array}{c}-14.720 \\
(3.249)^{* * *}\end{array}$ & & $\begin{array}{c}-17.274 \\
(5.745)^{* * *}\end{array}$ & & \\
\hline leverage sensitivity & & $\begin{array}{c}-35.710 \\
(21.509)^{*}\end{array}$ & & & \\
\hline creditor rights & $\begin{array}{c}5.841 \\
(2.070)^{* * *}\end{array}$ & & $\begin{array}{c}12.315 \\
(3.663)^{* * *}\end{array}$ & & \\
\hline RR & & & & $\begin{array}{c}0.715 \\
(0.136)^{* * *}\end{array}$ & $\begin{array}{c}0.741 \\
(0.171)^{* * *}\end{array}$ \\
\hline Constant & $\begin{array}{c}-142.241 \\
(36.014)^{* * *}\end{array}$ & $\begin{array}{l}-123.435 \\
(94 . .804)\end{array}$ & $\begin{array}{l}-119.288 \\
(87.025)\end{array}$ & $\begin{array}{c}-176.233 \\
(31.304)^{* * *}\end{array}$ & $\begin{array}{l}-28.977 \\
(88.822)\end{array}$ \\
\hline $\begin{array}{l}\text { Obs. } \\
\mathrm{R}^{2}\end{array}$ & $\begin{array}{c}129 \\
0.6003\end{array}$ & $\begin{array}{c}47 \\
0.5635\end{array}$ & $\begin{array}{c}47 \\
0.5369\end{array}$ & $\begin{array}{c}129 \\
0.5957\end{array}$ & $\begin{array}{c}47 \\
0.5063\end{array}$ \\
\hline
\end{tabular}

Notes: 1 . The table reports the results from the estimation of equation (5):

$c r_{-} g d p_{i}=\alpha_{0} f f_{i}+\alpha_{1} x_{i}+e_{i}$

The first column reproduces the results of Djankov et al. (2007). The second column reports the estimation results from the model that includes $L S$ as a measure of financial frictions. The third column reports the estimation results obtained from the Djankov et al. (2007) model when the countries in the sample are limited to the 47 countries for which $L S$ could be computed. The fourth and fifth columns replicate the experiments using recovery rates as a measure of financial frictions.

2. Data definitions are provided in Appendix A.

3. * significant at $10 \% ; * *$ significant at $5 \% ; * * *$ significant at $1 \%$.

4. Cross-section regressions estimated by Ordinary Least Squares (OLS). Robust standard errors in parentheses.

Table 7. Private credit and financial frictions - Subperiods

\begin{tabular}{|c|c|c|c|c|}
\hline Dependent variable: Private Credit/GDP & 1995-1997 & 1998-2001 & 2002-2005 & $2006-2008$ \\
\hline \multirow[t]{2}{*}{ leverage sensitivity } & -37.031 & -33.946 & -12.538 & -0.736 \\
\hline & $(9.971)^{* * *}$ & $(16.264)^{* *}$ & $(7.180)^{*}$ & $(14.572)$ \\
\hline \multirow[t]{2}{*}{ GDP per capita } & 8.267 & 14.182 & 22.583 & 25.143 \\
\hline & $(5.940)$ & $(8.209)^{*}$ & $(4.293)^{* * *}$ & $(6.308)^{* * *}$ \\
\hline \multirow[t]{2}{*}{ GDP per capita growth } & 12.600 & 8.680 & 3.534 & 6.385 \\
\hline & $(36.863)$ & $(5.379)^{*}$ & $(3.545)$ & $(5.733)$ \\
\hline \multirow[t]{2}{*}{ avginf } & 0.326 & 0.197 & -0.062 & -0.183 \\
\hline & $(0.211)$ & $(0.262)$ & $(0.168)$ & $(0.116)$ \\
\hline \multirow[t]{2}{*}{ Constant } & -48.133 & -24.755 & -17.633 & -19.885 \\
\hline & $(41.744)$ & $(43.491)$ & $(22.247)$ & $(35.100)$ \\
\hline Obs. & 47 & 47 & 47 & 47 \\
\hline $\mathrm{R}^{2}$ & 0.2849 & 0.2018 & 0.4279 & 0.4140 \\
\hline
\end{tabular}

Notes: 1. Table 7 reports the results from the estimation of equation (5) for 4 consecutive periods. $L S$ measures financial frictions. $c r \_g d p_{i}=\alpha_{0} f f_{i}+\alpha_{1} x_{i}+e_{i}$

2. Data definitions are provided in Appendix A.

3. * significant at $10 \% ; * *$ significant at $5 \% ; * * *$ significant at $1 \%$.

4. Cross-section regressions estimated by Ordinary Least Squares (OLS). Robust standard errors in parentheses. 
Table 8. The effect of bankruptcy reforms on financial frictions

\begin{tabular}{|c|c|c|c|c|c|c|}
\hline country & date in effect & $\Delta \mathrm{LS}$ & $\Delta \mathrm{CR}$ & $\Delta$ time & $\Delta \operatorname{cost}$ & $\Delta \mathrm{RR}$ \\
\hline Argentina & May-02 & $\begin{array}{c}-0.50 \\
(0.23)^{* *}\end{array}$ & 0.0 & - & - & - \\
\hline Mexico & May-00 & $\begin{array}{c}-0.44 \\
(0.11)^{* * *}\end{array}$ & 0.0 & - & - & - \\
\hline Belgium & Jan-98 & $\begin{array}{l}-0.11 \\
(0.18)\end{array}$ & 0.0 & - & - & - \\
\hline Brazil & Jun-05 & $\begin{array}{l}-0.09 \\
(1.56)\end{array}$ & - & -6.0 & 3.0 & 14.4 \\
\hline China & Jun-07 & $\begin{array}{c}0.22 \\
(0.20)\end{array}$ & 0.7 & -0.7 & 0.0 & 4.1 \\
\hline Germany & Jan-99 & $\begin{array}{c}0.05 \\
(0.02)^{* *}\end{array}$ & 0.0 & - & - & - \\
\hline Indonesia & Aug-98 & $\begin{array}{l}-0.05 \\
(0.04)\end{array}$ & -1.0 & - & - & - \\
\hline Italy & Jan-08 & $\begin{array}{l}-0.02 \\
(0.02)\end{array}$ & 0.0 & 0.0 & 0.0 & 5.9 \\
\hline Japan & Apr-00 & $\begin{array}{c}-0.10 \\
(0.05)^{*}\end{array}$ & -1.0 & - & - & - \\
\hline Korea, South & Apr-06 & $\begin{array}{l}-0.12 \\
(0.24)\end{array}$ & 0.0 & 0.0 & 0.0 & 0.6 \\
\hline Russia & Dec-02 & $\begin{array}{l}0.17 \\
0.13\end{array}$ & 1.0 & - & - & - \\
\hline Spain & Sep-04 & $\begin{array}{c}-0.16 \\
(0.09)^{*}\end{array}$ & 1.0 & 0.0 & 0.0 & -0.2 \\
\hline Thailand & Feb-99 & $\begin{array}{l}-0.05 \\
(0.04)\end{array}$ & -1.0 & - & - & - \\
\hline
\end{tabular}

Notes: 1. The second column of the table reports the change in $L S$ after the bankruptcy reform episodes listed in Appendix B (the first column reports the dates the new laws were put into effect). A 3-year period window is used to measure the mean values of $L S$ before and after the new bankruptcy law was put into effect. Columns 2, 3, 4 and 5 repeat the experiment by using $C R$, time, cost, and recovery rates as measures of financial frictions respectively.

2. The $t$-statistics in parantheses are based on tests used to determine whether $L S$, in the 3-year period following the enactment of the new law is significantly different from $L S$ measured in the 3-year period prior to the enactment.

3. * significant at $10 \% ; * *$ significant at $5 \% ; * * *$ significant at $1 \%$. 
Figure 1: Credit Supply/GDP

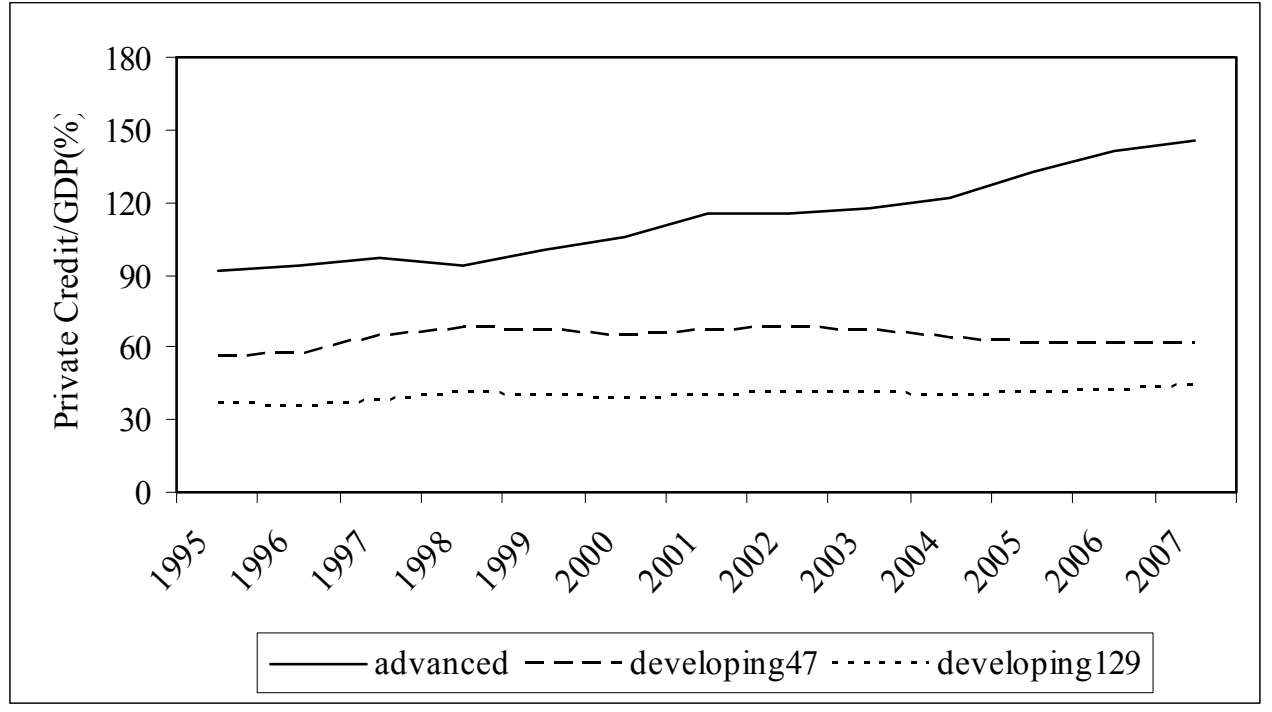

Notes: The figure displays the simple average of credit supply to GDP ratios for 3 country groups. To determine whether an economy is advanced or developing the IMF (2009) classification is used. Developing 47 denotes the average ratios for the developing countries in the sample used to measure LS. Developing 129 denotes the average ratios for the developing countries in the sample of Djankov et al. (2007). 